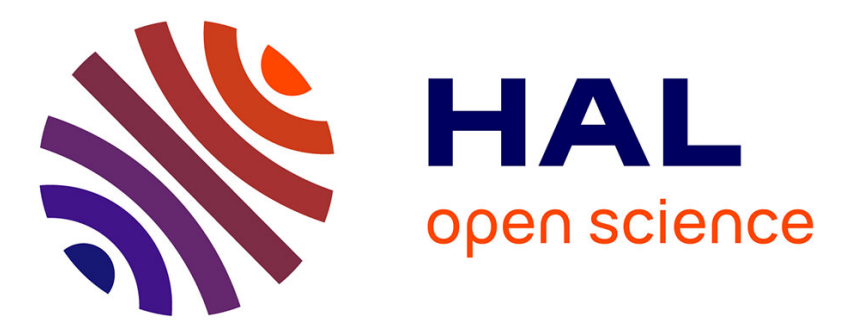

\title{
Polygenic chamosite from a hydrothermalized oolitic ironstone (Saint-Aubin-des-Châteaux, Armorican Massif, France): crystal chemistry, visible-near-infrared spectroscopy (red variety) and geochemical significance
} Yves Moelo, Emmanuel Fritsch, Eric Gloaguen, Olivier Rouer

\section{To cite this version:}

Yves Moelo, Emmanuel Fritsch, Eric Gloaguen, Olivier Rouer. Polygenic chamosite from a hydrothermalized oolitic ironstone (Saint-Aubin-des-Châteaux, Armorican Massif, France): crystal chemistry, visible-near-infrared spectroscopy (red variety) and geochemical significance. Clay Minerals, 2020, 55 (1), pp.83-95. 10.1180/clm.2020.13 . hal-02903077

\section{HAL Id: hal-02903077 \\ https://hal.science/hal-02903077}

Submitted on 17 Aug 2020

HAL is a multi-disciplinary open access archive for the deposit and dissemination of scientific research documents, whether they are published or not. The documents may come from teaching and research institutions in France or abroad, or from public or private research centers.
L'archive ouverte pluridisciplinaire HAL, est destinée au dépôt et à la diffusion de documents scientifiques de niveau recherche, publiés ou non, émanant des établissements d'enseignement et de recherche français ou étrangers, des laboratoires publics ou privés. 
Polygenic chamosite from an hydrothermalized oolitic ironstone (Saint-Aubin-des-

Châteaux, Armorican Massif, France): crystal chemistry, Vis-NIR spectroscopy (red variety) and geochemical significance.

Y. Moëlo ${ }^{1, *}$, E. Fritsch ${ }^{1}$, E. Gloaguen ${ }^{2,3}$ and O. Rouer ${ }^{4}$

${ }^{1}$ Université de Nantes, CNRS, Institut des Matériaux Jean Rouxel, IMN, F-44000 Nantes,

France

${ }^{2}$ BRGM, 3, avenue Claude Guillemin, BP 36009, 45060 Orléans cedex 2, France

${ }^{3}$ ISTO, UMR 7327, Université d'Orléans, CNRS, BRGM, F-45071 Orléans, France

${ }^{4}$ Laboratoire Georessources, UMR 7359, FST-SCMEM, Université de Lorraine, BP 70239 54506 Vandouvre les Nancy Cedex, France

[Received: xx xxxx 2018; revised: xx xxxx 2019; Associate Editor: J. Cuadros]

Running head: Polygenic chamosite from Saint-Aubin-des-Châteaux, France

DOI:

*E-mail: Yves.Moelo@cnrs-imn.fr

ABSTRACT: Several generations of chamosite, including a red variety, are known in the Ordovician hydrothermalized oolitic ironstone from Saint-Aubin-des-Châteaux

(Armorican Massif, France). Their chemical re-examination indicates a low Mg content $(0.925<\mathrm{Fe} /(\mathrm{Fe}+\mathrm{Mg})<0.954)$, but a significant variation of ${ }^{\mathrm{IV}} \mathrm{Al}$. Minor vanadium is

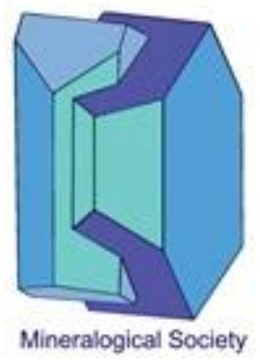

This is a 'preproof' accepted article for Clay Minerals. This version may be subject to change during the production process.

DOI: $10.1180 / \mathrm{clm} .2020 .13$ 
present up to $1.1 \mathrm{wt} . \%$ oxide. Variation of ${ }^{\mathrm{IV}} \mathrm{Al}$, vanadium content, and colour of chamosite are related to the hydrothermal reworking of the ironstone. Taking into account other published data, chamosite ideal composition is $\left(\mathrm{Fe}_{5-\mathrm{x}} \mathrm{Al}_{1+\mathrm{x}}\right)\left(\mathrm{Si}_{3-\mathrm{x}} \mathrm{Al}_{1+\mathrm{x}}\right) \mathrm{O}_{10}(\mathrm{OH})_{8}$, with $0.2<x<0.8$ (0.2: equilibrium with quartz; 0.8: $\mathrm{SiO}_{2}$ deficit). The red chamosite (IIb polytype) has a mean composition of $\left(\mathrm{Fe}_{3.87} \mathrm{Mg}_{0.23} \mathrm{Mn}_{0.01} \square_{0.07} \mathrm{Al}_{1.74} \mathrm{~V}_{0.07}\right)\left(\mathrm{Si}_{2.33} \mathrm{Al}_{1.67}\right) \mathrm{O}_{10}(\mathrm{OH})_{8}$. This chamosite is strongly pleochroic, from pale yellow $[\mathbf{E} / /(001)]$ to deep orangy red $[\mathbf{E} \perp(001)]$. Visible Near infra-red absorbance spectra show a specific absorption band centred around $550 \mathrm{~nm}$ for $\mathbf{E} \perp$ (001), due to a proposed new variety of Fe/V intervalence charge-transfer mechanism in the octahedral sheet, possibly $\mathrm{Fe}^{2+}-\mathrm{V}^{4+} \rightarrow \mathrm{Fe}^{3+}-\mathrm{V}^{3+}$. While the formation of green chamosite varieties is controlled by reducing conditions due to organic matter as a buffer, that of red chamosite would indicate locally a weak increase of $f\left(\mathrm{O}_{2}\right)$ related to oxidizing hydrothermal solutions.

Keywords: chamosite, crystal chemistry, visible-NIR spectroscopy, vanadium, Armorican Massif, France.

\section{INTRODUCTION}

In the sandstone quarry of Saint-Aubin-des-Châteaux (Loire-Atlantique department, Armorican Massif, France), an Ordovician oolitic ironstone (Chauvel, $1971 \&$ 1974) presents, together with ordinary green chlorite, a striking variety of "red chlorite", observed in the past during petrographic studies (G. Cornen, oral com.), and characterized later as a $\mathrm{Mg}$-poor chamosite (Gloaguen et al., 2007). This last study established different chamosite generations, and provided the opportunity for their detailed chemical study. In addition, an optical study was performed on the red chamosite, in order to understand its place within the sequence of 
chamosite generations, and the origin of its colour.

At Saint-Aubin-des-Châteaux the oolitic ironstone, submitted to a weak metamorphism (anchizone), is mainly composed of siderite and chamosite, with abundant organic matter (vitrinite; reflectance $\mathrm{R}=3.9 \pm 0.2 \%$ ). Later, this ironstone was hydrothermally altered by early Variscan polyphased fluids flows (Gloaguen et al., 2007; Tartèse et al., 2015) related to a 360 Ma old mafic magmatism (Pochon et al., 2016a, b). It induced specific mineralizations (Pochon et al., 2017, 2018), including Saint-Aubin-des-Châteaux sulfide ore (Pochon et al., 2019). In this deposit the oolitic ironstone was partly transformed into pyritised lenticular bodies and associated chlorite alteration haloes. It was followed by additional fracturing stages, that trapped base metals $(\mathrm{Pb}, \mathrm{Zn}, \mathrm{Cu}, \mathrm{Sb}$ and minor $\mathrm{Au})$. This hydrothermal process leads to a peculiar mineralogy, highlighted by the formation of lulzacite $\mathrm{Sr}_{2} \mathrm{Fe}^{2+}\left(\mathrm{Fe}^{2+}\right.$, $\mathrm{Mg})_{2} \mathrm{Al}_{4}\left(\mathrm{PO}_{4}\right)_{4}(\mathrm{OH})_{10}$ (type locality, Moëlo et al., 2000), pretulite $\mathrm{ScPO}_{4}$ (Moëlo et al., 2002), tobelite $\left[\left(\mathrm{NH}_{4}\right), \mathrm{K}\right] \mathrm{Al}_{2}\left(\mathrm{Si}_{3} \mathrm{Al}\right) \mathrm{O}_{10}(\mathrm{OH})_{2}$ (Mesto et al., 2012; Capitani et al., 2016; Pochon et al., 2019), and Sr-rich apatite with REE phosphates (Moëlo et al., 2008).

The hydrothermal process was governed by three geochemical reactions:

- Leaching of siderite by acid solutions, which were neutralized;

- Sulfidation (pyritisation) by combination of Fe from dissolved siderite with sulfur brought by the solution;

- Redox process: Oxidation of organic matter, partly dissolved, with re-precipitation of minor graphite lamellae. Inversely the hydrothermal solution was reduced.

As a whole, this process could be similar to the process of thermochemical sulfate reduction considered in the formation of Mississipi Valley-type lead-zinc ores (Leach et al., 2010).

There are several generations of chamosite in the Saint-Aubin deposit (Table 1Gloaguen et al., 2007). Primary chamosite (green), the most abundant variety, is the main 
constituent, together with the siderite cement, of primitive oolites in the sedimentary iron ore (ooidal ironstone), caused by diagenesis and low-grade metamorphism (Chauvel, 1971, 1974). Other chamosite generations (green and red) are related to the stages 1 to 3 of the hydrothermal process, in various ore facies (Table 1). The red chamosite is closely associated with the sulphide ore (stages 1 and 2). It has also been observed as isolated crystals disseminated in an apatite-rich sample, together with crystals of pretulite, $\mathrm{ScPO}_{4}$. Hydrothermal green chamosite has been observed in stage 1 (chlorite-pyrite facies; chloriterich reaction rim), stage 2 (lulzacite-bearing quartz-siderite veinlets; polymetallic quartz veins within sandstones), and stage 3 (tobelite-sulfosalt-gold quartz veins within sandstones).

According to Gloaguen et al., 2007, using chlorite as a geothermometer gives a formation temperature of about $290^{\circ} \mathrm{C}$ for metamorphic chamosite, followed by a T increase $(\sim 310-340$ $\left.{ }^{\circ} \mathrm{C}\right)$ for stage 1 , then a $\mathrm{T}$ decrease for stage $2\left(\sim 300^{\circ} \mathrm{C}\right)$, and stage $3\left(\sim 275^{\circ} \mathrm{C}\right)$.

Of particular interest is the late formation (stage 4) of berthierine, the $7 \AA$ Low-T dimorph of chamosite, also with an unusual brown colour (Moëlo et al., 2006), associated with quartz, minor kaolinite and europium-enriched apatite (Moëlo et al., 2008).

In the present study, the first part is devoted to the crystal chemical re-examination of the different chamosite generations, taking into account first electron-probe micro-analyses (EPMA) of Gloaguen et al. (2007), completed by new EPMA. The second part is focused on the spectroscopic study of red chamosite, in order to characterize its absorption bands in the visible-near infrared (Vis-NIR) range. In the third part, comparison of these data and geochemical constraints provides useful indications on the evolution of chamosite composition, and on the origin of the red colour of chamosite. We propose that such a colour originates from a new intervalence charge-transfert (IVCT) mechanism involving minor vanadium together with main iron. 
Chlorites are phyllosilicates with a $14 \AA$ A layer spacing, where a talc-like sheet ${ }^{V I}\left(R^{2+}, R^{3+}\right)_{3}{ }^{I V}\left(\mathrm{Si}, R^{3+}\right) \mathrm{O}_{10}(\mathrm{OH})_{2}$ alternates with a brucite sheet ${ }^{V I}\left(R^{2+}, R^{3+}\right)_{3}(\mathrm{OH})_{6}$ (Brown and Bailey, 1962). The cation $\mathrm{R}^{2+}$ is mainly $\mathrm{Mg}$ or $\mathrm{Fe}^{2+}$, and $R^{3+}$ mainly $\mathrm{Al}$ and $\mathrm{Fe}^{3+} \cdot{ }^{V I} R$ and ${ }^{I V} R$ correspond to octahedral and tetrahedral cations, respectively. Taking into account possible vacancies ( $\square$ ), their general structural formula is $\left({ }^{V I} R^{2+}{ }_{6-\mathrm{y}-\mathrm{z}}{ }^{V I} R^{3+}{ }_{\mathrm{y}} \square_{\mathrm{z}}\right)\left({ }^{I V} \mathrm{Si}_{4-\mathrm{x}}{ }^{I V} R^{3+}{ }_{\mathrm{x}}\right) \mathrm{O}_{10}(\mathrm{OH})_{8}$ (Bailey, 1980). For charges to be balanced, $y=x+2 z$.

Clinochlore is the species with major $\mathrm{Mg}^{2+}$ and $\mathrm{Al}^{3+}$, with ideal formula $\left(\mathrm{Mg}_{5} \mathrm{Al}\right)\left(\mathrm{Si}_{3} \mathrm{Al}\right) \mathrm{O}_{10}(\mathrm{OH})_{8}$ (no vacancy: purely trioctahedral). Chamosite is the $\mathrm{Fe}^{2+}$ endmember, with ideal formula $\left(\mathrm{Fe}_{5} \mathrm{Al}\right)\left(\mathrm{Si}_{3} \mathrm{Al}\right) \mathrm{O}_{10}(\mathrm{OH})_{8}$ proposed by Bayliss (1975). The crystal chemical classification of chlorites by Wiewióra \& Weiss (1990) takes also into account the vacancy content as well as the Tschermak substitution rule ${ }^{\mathrm{VI}} R^{2+}+{ }^{\mathrm{IV}} \mathrm{Si}^{4+} \leftrightarrow{ }^{\mathrm{VI}} \mathrm{Al}^{3+}+{ }^{\mathrm{IV}} \mathrm{Al}^{3+}$. Recently, Trincal \& Lanari (2016) have proposed a new substitution rule, correlating $\mathrm{Fe}^{3+}$ and vacancy: $3\left(\mathrm{Mg}, \mathrm{Fe}^{2+}\right) \rightarrow 2 \mathrm{Fe}^{3+}+\square$.

Chlorites show six polytypic groups (Bailey, 1988; Inoué \& Kogure, 2016), with various types of stacking disorder (Brindley, 1980). Interstratification with other phyllosilicates, minerals of the serpentine group as well as smectite, are common. Particularly, interstratification between chamosite and berthierine is commonly observed (Jiang et al., 1992; Inoué \& Kogure, 2016).

In the clinochlore-chamosite solid-solution, the relationships between chemistry and unit cell are controlled by several factors:

1. A steric factor due to Fe substituting for $\mathrm{Mg}$ : The increase of ${ }^{\mathrm{IV}} \mathrm{Al}^{3+}$ with that of the $\mathrm{Fe} /(\mathrm{Fe}+\mathrm{Mg}$ ) ratio obeys to steric constraints (Shau \& Peacor, 1992). The expansion of the octahedral sheets, due to the Fe-for-Mg substitution, induces an expansion of the tetrahedral 
sheets, obtained through the $\mathrm{Al}^{3+}$-for- $\mathrm{Si}^{4+}$ substitution;

2. Charge balance: This second substitution corresponds to a charge deficit, which ought to be compensated by a charge increase in the octahedral sheet, according to the $\mathrm{Al}^{3+}$-for- $M e^{2+}$ substitution. This retroactive effect reduces the expansion of the octahedral sheet: for one Al atom substituting one $\mathrm{Si}$ atom among four tetrahedral positions, one $\mathrm{Al}$ atom substitutes one $M e^{2+}$ among six octahedral positions. This Tschermak substitution explains the abnormal slight $c$ decrease with increasing $\mathrm{Fe} /(\mathrm{Fe}+\mathrm{Mg}$ ) ratio (Hey, 1954; McOnie et al., 1975);

3. Phase equilibrium: at constant $\mathrm{Fe} /(\mathrm{Fe}+\mathrm{Mg})$ ratio, the Tschermak substitution may also operate secondly according to the $\mathrm{Al} / \mathrm{Si}$ ratio of the system. $\mathrm{A} \mathrm{SiO}_{2}$ excess will impose a low

${ }^{\mathrm{IV}} \mathrm{Al}$, whereas a $\mathrm{SiO}_{2}$ deficit will result in a high ${ }^{\mathrm{IV}} \mathrm{Al}$, as is documented in Saint-Aubin;

4. Vacancies in the octahedral sheets, according to the dioctahedral substitution $3 \mathrm{Me}^{2+} \rightarrow$ $2 \mathrm{Me}^{3+}+\square$, will induce a contraction of these sheets, and thus counterbalance the expansion due to $\mathrm{Fe} / \mathrm{Mg}$ substitution.

In the present study, two stoichiometric compositions (Mg- and vacancy-free) have been taken as references to discuss the chamosite crystal chemistry: one Al-poor, $\left(\mathrm{Fe}_{5} \mathrm{Al}\right)\left(\mathrm{Si}_{3} \mathrm{Al}\right) \mathrm{O}_{10}(\mathrm{OH})_{8}$, frequently encountered in mineralogical databases, and the second Al-rich, $\left(\mathrm{Fe}_{4} \mathrm{Al}_{2}\right)\left(\mathrm{Si}_{2} \mathrm{Al}_{2}\right) \mathrm{O}_{10}(\mathrm{OH})_{8}$.

\section{MATERIALS AND ANALYTICAL METHODS}

Selected chamosite-bearing samples were prepared as polished thin sections and polished sections for microscopic study, EPMA, and optical study. Additional, isolated single crystals of red chamosite have been extracted from an apatite-rich sample for X-ray examination. Samples were first observed under the binocular loupe and through the polarizing microscope 
(in transmitted and reflected light), to select chamosite varieties, and determine their mineral associations (Table 1).

Microprobe analysis

All EPMA were obtained at the BRGM-CNRS-University common laboratory (Orléans), with a CAMECA SX50 apparatus, with a voltage of $15 \mathrm{kV}$ and a beam current of $12 \mathrm{nA}$.

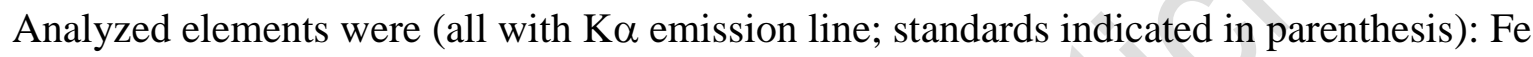
$\left(\mathrm{Fe}_{2} \mathrm{O}_{3}\right), \mathrm{Mn}\left(\mathrm{Mn}_{2} \mathrm{O}_{3}\right), \mathrm{Mg}$ (olivine), $\mathrm{Al}$ (albite), $\mathrm{V}$ (vanadinite), $\mathrm{Si}$ (albite), and $\mathrm{Ti}\left(\mathrm{MnTiO}_{3}\right)$. Minor elements ( $\leq 0.1$ wt.\% oxide) detected by Gloaguen et al. (2007), but not essential in the crystal chemistry of chlorite (i.e. $\mathrm{Ca}, \mathrm{Ba}, \mathrm{Zn}, \mathrm{Cu}, \mathrm{K}, \mathrm{Na}, \mathrm{F}, \mathrm{Cl}$ ), have been omitted. $\mathrm{H}_{2} \mathrm{O}$ content (wt.\%) has been added on the basis of $4 \mathrm{H}_{2} \mathrm{O}$ for $14 \mathrm{O}$ of the oxide total, to fit the ratio $\mathrm{O}_{10}(\mathrm{OH})_{8}$ of the structural formula.

$X$-ray study

Dissemination of red chamosite in the sulfide ore precluded obtaining a precise powder Xray diffraction (XRD) pattern, which would establish its polytype, and thus detecting possible interstratification with berthierine, as commonly observed by Inoué \& Kogure (2016) in chamosite from hydrothermal ores. Nevertheless, dissolution in hydrochloric acid of abundant apatite in a pretulite-bearing sample made it possible to extract single crystals of red chamosite. One crystal was mounted on a glass capillary for a single-crystal X-ray diffraction study with a Nonius Kappa CCD diffractometer using Mo- $K \alpha$ radiation (operator: A. Meerschaut, IMN). 


\section{Optical study}

Optical study was focused on pure red chamosite, without neighbouring green variety. Thin sections containing red chamosite crystals were investigated with visible light (410-760 $\mathrm{nm})$. Transmitted spectra have been acquired using a LEICA DMR polarizing microscope equipped with a MPV-SP micro-photometer. The band width of the monochromator was $\Delta \lambda=$ $2 \mathrm{~nm}$. Computation of colour values and their representation in a chromaticity diagram have been performed according to the protocol detailed by Criddle (1990, and references therein), taking illuminant C (“average daylight” - colour temperature $6774 \mathrm{~K}$ ) of the CIE (Commission Internationale de l'Eclairage) as the standard for white colour.

The absorption spectra in the visible - near-infra-red (Vis-NIR) range (340 to $2500 \mathrm{~nm}$, i.e. $29400-4000 \mathrm{~cm}^{-1}$ ) have been acquired in transmitted light on the same thin sections (standard thickness of $30 \mu \mathrm{m}$ ). A Varian Cary 5000 double beam absorption spectrophotometer was used with a sampling interval of $1 \mathrm{~nm}$, and a $1 \mathrm{~nm}$ spectral band width. The sample measured was a thin section of a red chamosite lamella with the polarization direction parallel or perpendicular to the elongation of the lamella. The glass and glue support were compensated by a similar set-up on the reference beam: A standard glass slab for lithographic thin section, as used for the sample, was covered on a region larger than the UV-Visible beam section with the exact same glue. This was then turned into a very thin bevel, to offer all possible equivalent of glue thickness, and then the position of the bevel in the beam was adjusted to compensate for a potential small glue contribution, which is indeed rare.

\section{RESULTS}


Microprobe analyses

Table 2a gives microprobe analyses as wt.\% oxides, with divalent $\mathrm{Fe}$ and $\mathrm{Mn}$, and trivalent $\mathrm{V}$, according to the strongly reducing conditions indicated by the abundance of organic matter in the primitive oolitic iron ore, and the presence of ammonium-mica (tobelite). Table $2 \mathrm{~b}$ indicates the structural formulae on the basis of $\mathrm{O}_{10}(\mathrm{OH})_{8}$ as the anionic counterpart.

Main components. The diagram of Fig. 1a represents analyses as ${ }^{\mathrm{IV}} \mathrm{Al}$ versus $\mathrm{Fe} /(\mathrm{Fe}+$ $\mathrm{Mg}$ ) ratio. As indicated first by Chauvel (1971), and further demonstrated by Gloaguen et al. (2007), Fe largely predominates over $\mathrm{Mg}(\mathrm{Fe} / \mathrm{Mg}>12)$ in Saint-Aubin. The majority of analyses is restricted to a $\mathrm{Fe} /(\mathrm{Fe}+\mathrm{Mg})$ ratio close to $0.946( \pm 0.006)$. On the contrary, there is a significant variation of ${ }^{\mathrm{IV}} \mathrm{Al}$ (i.e. of the Tschermak substitution rule), from 1.41 up to 1.80 .

Vacancies. Table $2 \mathrm{~b}$ gives a low vacancy content, between 0.005 and 0.17 octahedral sites per $\mathrm{O}_{10}(\mathrm{OH})_{8}$. Fig. $1 \mathrm{~b}$ represents the projection of chamosite compositions on the diagram Si versus $\mathrm{Me}^{2+}$, according to Wiewióra \& Weiss (1990), as used by Hillier \& Velde (1991). This diagram visualizes vacancy concentration.

Trivalent $\mathrm{Fe}: \mathrm{Fe}^{3+}$ may significantly substitute for ${ }^{\mathrm{VI}} \mathrm{Al}^{3+}$, for instance in "orthochamosite" (Novak et al., 1959), with ideal composition $\left[\left(\mathrm{Fe}^{2+}, \mathrm{Mg}, \mathrm{Fe}^{3+}\right)_{5} \mathrm{Al}\right]\left(\mathrm{Si}_{3} \mathrm{Al}\right) \mathrm{O}_{10}(\mathrm{OH}, \mathrm{O})_{8}$. Nevertheless, microprobe analysis does not permit to reveal minor $\mathrm{Fe}^{3+}$ in chamosite from Saint-Aubin.

Distribution of minor transition metals. Together with major iron, V, Mn and Ti are the three transition metals detected as minor constituents (Table 2). $\mathrm{Zn}$ and $\mathrm{Cu}$, rarely detected by Gloaguen et al. (2007) (maxima 0.12 and 0.04 wt.\% oxide, respectively) in chamosite from stage 1 , may correspond to sulfide contamination. The Ti content is always very low $(\leq 0.03$ wt.\% oxide), that of Mn a little bit higher (0.06 to 0.29 wt.\% oxide). 
On the contrary, the vanadium content, more heterogeneous (Gloaguen et al., 2007), may reach over 1 wt. \% oxide. Vanadium zoning can be observed. For instance, the centre of a lamella of red chamosite (No 10, Table 2a) is enriched with $\mathrm{V}$ and $\mathrm{Al}$ relatively to the rim (No 11). Correlatively, Mn and Ti, both very low (Table 2a), increase slightly.

Late brown berthierine, formed at low temperature at the expense of lulzacite (which has 0.64 wt. $\% \mathrm{~V}_{2} \mathrm{O}_{5}-$ Moëlo et al, 2000), also contains minor $\mathrm{V}\left(0.46\right.$ wt. $\% \mathrm{~V}_{2} \mathrm{O}_{3}-$ Table $\left.2 \mathrm{a}\right)$. $\mathrm{Mn}$ and Ti are negligible. In equilibrium with kaolinite and quartz, berthierine has the Al-poor composition $\left(\mathrm{Fe}_{3.90} \mathrm{Mg}_{0.24} \square_{0.15} \mathrm{Al}_{1.67} \mathrm{~V}_{0.04}\right)\left(\mathrm{Si}_{2.56} \mathrm{Al}_{1.44}\right) \mathrm{O}_{10}(\mathrm{OH})_{8}$, very close to that of late green chamosite No 16 (Table 2b).

\section{Crystallography}

X-ray single crystal study of red chamosite (No 5, Table 2) gave a monoclinic unit cell, space group $C 2 / m$, with $a=5.375(1), b=9.322(2), c=14.177(3) \AA, \beta=97.43(3)^{\circ}$, and $V=$ 704.4 $\AA^{3}$. According to EPMA results (Table 2), it has the structural formula $\left(\mathrm{Fe}_{3.68} \mathrm{Mg}_{0.30} \mathrm{Mn}_{0.01} \square_{0.11} \mathrm{Al}_{1.83} \mathrm{~V}_{0.08}\right)\left(\mathrm{Si}_{2.30} \mathrm{Al}_{1.70}\right) \mathrm{O}_{10}(\mathrm{OH})_{8}$. This formula most closely corresponds to polytype II $b$, the most common chlorite polytype (Brown \& Bailey, 1962). Thus, although the relatively poor quality of the X-ray pattern was not suitable for detailed crystal structure investigations, it is safe to assume a II $b$ polytype for the red chamosite.

\section{Optical study of red chamosite}

Visible transmission spectra. Under the binocular loupe, sub-millimetric individual crystals of red chamosite present a brown colour. In thin section, red chamosite observed under the microscope with polarized light shows a very strong pleochroism, from near-white 
to deep orangey red (Fig. 2). This pleochroism is of the normal type (Richardson \& Richardson, 1982), i.e. the selective absorption giving the strong coloring is maximal when the polarization plane is parallel to the elongation of the chamosite lamella $[\mathbf{E} \|(001)]$.

Figure 3 presents the two visible transmittance spectra (VTS) obtained with the polarization plane perpendicular (A, blue) or parallel (B, red) to the lamella plane, respectively. In $\mathrm{A}[\mathbf{E} \perp(001)]$ the transmittance is highest in the middle of the spectrum (560$620 \mathrm{~nm}$ ), with a regular decrease down to about $50 \%$ at the two ends of the spectrum. Inversely, in B [E $\mid(001)]$, the transmittance is nil from 420 to $540 \mathrm{~nm}$, with a weak transmittance window $(\sim 40 \%)$ centred near $700 \mathrm{~nm}$. These data show the very strong absorption for $\mathrm{E} \|(001)$.

In the chromaticity diagram (Fig. 4), the coordinates of A and B spectra are $\mathrm{x}_{\mathrm{C}}=0.34, \mathrm{y}_{\mathrm{C}}$ $=0.36$, and $\mathrm{x}_{\mathrm{C}}=0.63, \mathrm{y}_{\mathrm{C}}=0.33$, respectively. Point $\mathrm{A}$, close to the CIE illuminant $\mathrm{C}$ (white daylight), corresponds to a pale yellow (dominant wavelength $\lambda_{\mathrm{D}}=572 \mathrm{~nm}$; excitation purity $\left.\mathrm{P}_{\mathrm{e}} \sim 15 \%\right)$, while point $\mathrm{B}$ corresponds to a saturated orangey red $\left(\lambda_{\mathrm{D}}=610 \mathrm{~nm} ; \mathrm{P}_{\mathrm{e}} \sim 90 \%\right)$.

Visible-NIR absorbance spectra. The two preceding transmitted-light spectra correspond to the left half of part I of the Fig. 5, which presents the two Vis-NIR absorbance spectra of red chamosite: A [blue "perpendicular" $-\mathbf{E} \perp(001)]$, and B [red "parallel” - E $\|(001)]$.

All well-defined absorption bands as well as some possible minor ones have been indexed, and listed in Table 3. These Vis-NIR spectra can be divided in two parts:

- Part I (from 340 to $1350 \mathrm{~nm}$ ) is dominated by electronic transitions. It shows in A a strong complex absorption band between 650 and $1350 \mathrm{~nm}$, together with a continuum rising towards the UV. The complex band is the sum of a main band at about $915 \mathrm{~nm}$, with a second band around $1100 \mathrm{~nm}$. The continuum shows possibly very weak bands at $\sim 460,605$ and 645 nm.

In B the two main components of the complex band are centred around 895 and $\sim 1110$ 
$\mathrm{nm}$, with a weak band on its left flank, around $710 \mathrm{~nm}$. Below $650 \mathrm{~nm}$, one observes, surimposed on the sloping continuum, a broad $\left(\Delta v_{1 / 2} \sim 3700 \mathrm{~cm}^{-1}-\right.$ graphic estimation $)$ and strong absorption band centred around $550 \mathrm{~nm}\left(\sim 18200 \mathrm{~cm}^{-1}\right)$, inducing the absorption of the green colour. It corresponds to the loss of transmittance observed in spectrum B of Fig. 3 .

- Part II (from 1350 to $2500 \mathrm{~nm}$ ) is very similar in A and B spectra. It shows weaker absorption bands, dominated by vibrational transitions, with two sub-parts:

1. A small sharp peak at $1415 \mathrm{~nm}$, followed by three ill-defined broad peaks at 1580,1720 and $~ 1770 \mathrm{~nm}$;

2. At wavelengths over $1850 \mathrm{~nm}$, a complex band composed (at least) of three distinct peaks at $\sim 2268,2320$ and $2370 \mathrm{~nm}$, preceded by two small bands at $\sim 2020$ and $2180 \mathrm{~nm}$.

\section{DISCUSSION}

\section{Geochemical evolution of chamosite at Saint-Aubin-des-Châteaux}

According to the paragenetic sequence (Table 1) and EPMA data (Fig. 1a), the lowest values of ${ }^{\mathrm{IV}} \mathrm{Al}$ correspond to chamosite associated with quartz, for instance in sandstone (No 15 and 16), or in lulzacite-bearing veinlets (No 13). Inversely, ${ }^{\mathrm{IV}} \mathrm{Al}$-rich chamosite (green and red, analyses No 2 to 11 ) is related to the beginning of the hydrothermal process (stages 1 and 2), with a strong contribution of the hydrothermal fluids. It would indicate a highest leaching of $\mathrm{SiO}_{2}$ relatively to $\mathrm{Al}_{2} \mathrm{O}_{3}$. Here their calculated formulas are closer to stoichiometric $\left(\mathrm{Fe}_{4} \mathrm{Al}_{2}\right)\left(\mathrm{Si}_{2} \mathrm{Al}_{2}\right) \mathrm{O}_{10}(\mathrm{OH})_{8}$ than to the classic chamosite formula $\left(\mathrm{Fe}_{5} \mathrm{Al}\right)\left(\mathrm{Si}_{3} \mathrm{Al}\right) \mathrm{O}_{10}(\mathrm{OH})_{8}$, with the Al-poorest compositions (analyses No 14, 15 and 16 - Table $2 \mathrm{~b}$ ) close to the middle of the solid solution, i.e. $\sim\left(\mathrm{Fe}_{4.5} \mathrm{Al}_{1.5}\right)\left(\mathrm{Si}_{2.5} \mathrm{Al}_{1.5}\right) \mathrm{O}_{10}(\mathrm{OH})_{8}$. The average composition of red chamosite corresponds to $\mathrm{Fe} /(\mathrm{Fe}+\mathrm{Mg})=0.943( \pm 0.013)$, and ${ }^{\mathrm{IV}} \mathrm{Al}=1.673( \pm 0.035)$. 
The first chamosite sample from Saint-Aubin analysed by Chauvel (1971) was extracted from the primitive oolitic ore. The analysis gave a similar $\mathrm{Fe} /(\mathrm{Fe}+\mathrm{Mg})$ ratio $(0.946)$ but a lower $\mathrm{Al}$ content $\left({ }^{\mathrm{IV}} \mathrm{Al}=1.33\right)$. Such an $\mathrm{Al}$ deficit may be due to minor quartz admixture in the sample selected for wet chemical analysis.

The variation of vanadium content is related to the evolution of the ore deposit established by Gloaguen et al. (2007):

- Primitive green chamosite has a low V content ( 0.25 wt. \% oxide - analysis No 1, Table 2). Chamosite from the oolitic-chloritic facies (analysis No 3), with only $0.10 \mathrm{wt} \%$ oxide, apparently corresponds to residual primary chamosite, after dissolution of the siderite matrix of the oolitic iron ore at the beginning of stage 1;

- V content significantly increases in chamosite, green or red, crystallized during stages 1 and 2, up to 1.06 wt.\% oxide. In sample 11 (red chamosite), a crystal zoning indicates a V decrease from the centre to the rim (1.06 to 0.58 wt.\% oxide);

- Then, in next stages 2 and $3, \mathrm{~V}$ content decreases. In sulfide veins within the hydrothermalized ironstone (stage 2), V content is only $0.24 \mathrm{wt} . \%$ oxide. In final generations, that is in lulzacite-bearing quartz-siderite veinlets within the ironstone (stage 2), or in sulfide or sulfosalt quartz veins within surrounding sandstone (stages 2 and 3), the V content decreases to very low concentrations $(\leq 0.03 \mathrm{wt} . \%$ oxide). This decrease indicates a leaching of vanadium by late hydrothermal solutions.

There is no significant variation of the $\mathrm{TiO}_{2}$ content, always very low (0.01-0.03 wt.\%Table 2). MnO content is low (0.0-0.3 wt.\%), with a small enrichment in green chamosite of the stage 3 (up to $0.29 \mathrm{wt} \%$ ), while in red chamosite it does not exceed $0.12 \mathrm{wt} . \%$. 
Chamosite composition field from Saint-Aubin agrees with the general trend of an increase of ${ }^{\mathrm{IV}} \mathrm{Al}^{3+}$ with that of the $\mathrm{Fe} /(\mathrm{Fe}+\mathrm{Mg}$ ) ratio (Brown \& Bailey, 1962; Hillier \& Velde, 1991). On the basis of an extended chemical database on metamorphic chlorite, Zane et al. (1998) established a regression line between the clinochlore and chamosite poles, from $\mathrm{Mg}=4.81$ to $\mathrm{Fe}=4.38$ atoms, that is, if there are no vacancies, ${ }^{\mathrm{IV}} \mathrm{Al}$ from 1.19 up to 1.62. (Fig. 6a).

Fig. 6 a also shows the composition field of the main polytype II $b$ determined by Brown $\&$ Bailey (1962) on the basis of X-ray study. In Saint-Aubin, chamosite analyses fill the gap between the II $b$ field and the solid solution of pure chamosite II $b$ determined experimentally by Parra et al. (2005) in the $350-530{ }^{\circ} \mathrm{C}$ range, with $1.2<{ }^{\mathrm{IV}} \mathrm{Al}<1.8$ at. Also in Fig. 6 a are the compositions of chlorite samples with well resolved crystal structures (Table 4). Ordered triclinic clinochlore studied by Smyth et al. (1997), with ${ }^{\mathrm{IV}} \mathrm{Al}=1.04$ and $\mathrm{Fe} /(\mathrm{Fe}+\mathrm{Mg})=0.02$, can be taken as the reference for the $\mathrm{Mg}$ end-member. Only one crystal structure of chamosite $\mathrm{II} b\left(\mathrm{Mg}\right.$-rich) is known, that of Walker \& Bish (1992), with $\mathrm{Fe} /(\mathrm{Fe}+\mathrm{Mg}) \sim 0.6$, and ${ }^{\mathrm{IV}} \mathrm{Al}=$ 1.15. Up to now, there is no crystal structure data of $\mathrm{Mg}$-poor or $\mathrm{Mg}$-free chamosite of the most common II $b$ polytype.

McOnie et al. (1975) have established the variation of the unit cell in synthetic chlorites of the clinochlore-"daphnite" solid solution ("daphnite" = chamosite). The regular increase of the unit volume $\mathrm{V}$ with increasing ${ }^{\mathrm{VI}} \mathrm{Fe}^{2+}$ gives $\mathrm{V} \sim 712 \AA^{3}$ for the Fe end-member. According to Tschermak substitution, Parra et al. (2005) give V between 711 and $719 \AA^{3}$. On the basis of $\mathrm{Fe} /(\mathrm{Fe}+\mathrm{Mg})=0.94$, the unit cell of red chamosite would be (McOnie et al., 1975): $a=5.393$ $\AA, b=9.356 \AA, c=14.212 \AA, \beta=97.2^{\circ}$, and $V=711.4 \AA^{3}$. The lower values of measured $a, b$ and $c$ parameters of red chamosite $(5.375,9.322$ and $14.177 \AA$, respectively) relative to these calculated values are an artefact related to the X-ray single-crystal approach. One knows that disorder stacking in clay minerals induces a distortion of the profile of diffraction peaks 
towards higher $2 \theta$ values, i. e. lower interplanar distances (Brindley, 1980). As a consequence, mean positions of diffraction spots measured through X-ray single-crystal study will give lower values of unit-cell parameters. Moreover, interstratification with berthierine cannot be excluded, as it would not change significantly the chemical composition nor the

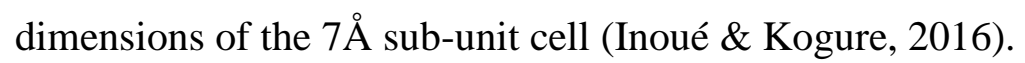

\section{Comparison with other Mg-poor chamosite occurrences}

Various occurrences of $\mathrm{Mg}$-poor chamosite have been described. Table 5 presents their structural formulas. Chamosite is a common component of oolitic ironstones, for instance in central Brittany (Chauvel, 1971), in Switzerland (Delaloye \& Odin, 1988), or in the Iberian Massif (Zamora, Spain - Fernández \& Moro, 1994). All are Al-rich $\left({ }^{\mathrm{IV}} \mathrm{Al}>1.3\right.$ atoms per four tetrahedral sites) and $\mathrm{Mg}$-poor $(\mathrm{Fe} /(\mathrm{Fe}+\mathrm{Mg})>0.85$ (Fig. 6b). One exception would be that of chamosite from the type deposit of Chamoson (Switzerland; analysis not shown). Its wet analysis (Delaloye \& Odin, 1988) indicates a very low ${ }^{\mathrm{IV}} \mathrm{Al}(\sim 0.88)$, together with a silica excess, probably due to quartz impurities. Unfortunately, EPMA results are lacking. "Bavalite" from the Devonian stratiform iron ore of Bas-Vallon (Central Brittany; Orcel, $1923)$ is a chamosite close to that of Saint-Aubin, with ${ }^{\mathrm{IV}} \mathrm{Al} \sim 1.46$, and $\mathrm{Fe} /(\mathrm{Fe}+\mathrm{Mg})=0.91$. Saint-Aubin chamosite represents the ${ }^{\mathrm{IV}} \mathrm{Al}$-richest and Mg-poorest compositions among oolitic ores.

In the Kidd Creek massive sulfide deposit (Ontario), the Mg-poorest chamosite analyses (Jiang, 1992) plot within the field of chamosite from Saint-Aubin (Fig. 6b). A very Mg-poor chamosite $\left({ }^{\mathrm{IV}} \mathrm{Al} \sim 1.44, \mathrm{Fe} /(\mathrm{Fe}+\mathrm{Mg})=0.983-\mathrm{Fig} .6 \mathrm{~b}\right)$ has been found in the Ashio polymetallic vein deposit (Japan - Inoué \& Kogure, 2016).

All these chamosite analyses are close to the solid-solution field of synthetic Mg-free 
chamosite of Parra et al. (2005). Clearly, all these data on natural Mg-poor as well as synthetic Mg-free chamosites have more $\mathrm{Al}$ than the stoichiometric formula $\left(\mathrm{Fe}_{5} \mathrm{Al}\right)\left(\mathrm{Si}_{3} \mathrm{Al}\right) \mathrm{O}_{10}(\mathrm{OH})_{8}$ given by Bayliss (1975) for the definition of this chlorite species. On the other hand, they have $\mathrm{Al}$ below the stoichiometric formula $\left(\mathrm{Fe}_{4} \mathrm{Al}_{2}\right)\left(\mathrm{Si}_{2} \mathrm{Al}_{2}\right) \mathrm{O}_{10}(\mathrm{OH})_{8}$. In a temperature range corresponding to metamorphic as well as high-temperature hydrothermal conditions, the ideal composition field (without vacancies) of the Fe-pure pole chamosite is restricted to a solid solution between $\left(\mathrm{Fe}_{4.8} \mathrm{Al}_{1.2}\right)\left(\mathrm{Si}_{2.8} \mathrm{Al}_{1.2}\right) \mathrm{O}_{10}(\mathrm{OH})_{8}$ and $\left(\mathrm{Fe}_{4.2} \mathrm{Al}_{1.8}\right)\left(\mathrm{Si}_{2.2} \mathrm{Al}_{1.8}\right) \mathrm{O}_{10}(\mathrm{OH})_{8}$ (Para et al., 2005). Thus, chemical analyses on natural as well synthetic samples show that chamosite is definitively a non-stoichiometric mineral species. It corresponds to the general formula $\left(\mathrm{Fe}_{5-\mathrm{x}} \mathrm{Al}_{1+\mathrm{x}}\right)\left(\mathrm{Si}_{3-\mathrm{x}} \mathrm{Al}_{1+\mathrm{x}}\right) \mathrm{O}_{10}(\mathrm{OH})_{8}$, with $0.2<x<0.8$.

\section{Interpretation of Vis-NIR spectra of red chamosite}

Vis-NIR spectra A and B can be compared with published spectra of members of the clinochlore-chamosite series. Faye (1968) gives absorptions of oriented lamellae of green chlorite with $5.2 \mathrm{wt} \% \mathrm{Fe}^{2+}$ and $0.6 \mathrm{wt} \% \mathrm{Fe}^{3+}$ in the range $8000-29000 \mathrm{~cm}^{-1}(1250-345 \mathrm{~nm})$. For a transverse section there are two bands at low energy $\left(11600\right.$ and $\left.9600 \mathrm{~cm}^{-1}\right)$, while for a basal section, together with the same bands at 11400 and $\sim 9500 \mathrm{~cm}^{-1}$, an additional feature is present at $14100 \mathrm{~cm}^{-1}$. In the unpolarized absorbance spectrum given by Platonov (1976) for chamosite, there are also three bands: 14300,11350 , and $9200 \mathrm{~cm}^{-1}$.

In the clinochlore-chamosite series, the two components around 11500 and $9500 \mathrm{~cm}^{-1}$ correspond to electronic transitions of octahedral $\mathrm{Fe}^{2+}$, while the third around $14300 \mathrm{~cm}^{-1}$ represents an intervalence charge-transfer (IVCT) between $\mathrm{Fe}^{2+}$ and $\mathrm{Fe}^{3+}$ in adjacent $\mathrm{M} 1$ and M2 octahedra (Platonov, 1976). This third component, absent in spectrum A, and weak in spectrum $\mathrm{B}\left(\sim 710 \mathrm{~nm} / 14085 \mathrm{~cm}^{-1}\right)$, indicates a very low $\mathrm{Fe}^{3+}$ content in red chamosite from 
Saint-Aubin. It would be interesting to quantify such a weak $\mathrm{Fe}^{3+}$ content of red chamosite through XANES measurement at the microscopic scale (Vidal et al., 2006; Trincal et al., 2015).

The weak band at $\sim 620 \mathrm{~nm}$ (Fig. 5) may correspond to the large absorption band at 609 $\mathrm{nm}$ observed in a green $\mathrm{V}$-rich, Fe-free muscovite, that corresponds to a $\mathrm{V}^{3+}$ electronic transition (Ertl et al., 2019).

Above $1350 \mathrm{~nm}$ (Part II of A and B spectra, Fig. 5), absorption bands correspond to overtones and combinations of the fundamental $\mathrm{OH}$ and $\mathrm{H}-\mathrm{O}-\mathrm{H}$ vibrations. At the shortest wavelengths, A and B spectra can be compared with the NIR spectrum obtained for clinochlore between 1350 and 1670 nm by Ferrage et al. (2003): two close sharp peaks at 1392 (main) and $1405 \mathrm{~nm}$, and two broad ones near 1440 and $1560 \mathrm{~nm}$. The first sharp peak, corresponding to the $\mathrm{OH}$-stretching mode of $\mathrm{Mg}_{3} \mathrm{OH}$, is not visible in red chamosite, due to its low Mg content. The second peak was tentatively assigned by Ferrage et al. (2003) to an $\mathrm{OH}-$ stretching mode of $\mathrm{Mg}_{2} \mathrm{AlOH}$. They relate the two other broad bands (1440 and $1560 \mathrm{~nm}$ ) to overtones of $\mathrm{OH}$-stretching fundamental modes of $(\mathrm{SiSi}) \mathrm{O}-\mathrm{OH}$ and $(\mathrm{SiAl}) \mathrm{O}-\mathrm{OH}$, respectively. The band of the first mode is not visible in Saint-Aubin sample, as would be expected from its low Si content.

Bishop et al. (2008) performed NIR reflectance spectra of clinochlore and chamosite. In clinochlore they found three bands at about 1400 (sharp), 1450 (broad) and $1550 \mathrm{~nm}$ (broad), then two broad bands at 1880 and $2000 \mathrm{~nm}$. All these bands are very weak (1400, 1890 and $2010 \mathrm{~nm}$ ) or lacking in chamosite. Like Ferrage et al. (2003), Mathian et al. (2018) observed a doublet at 1391 and $1406 \mathrm{~nm}$ for clinochlore, and at 1407 and $1415 \mathrm{~nm}$ for chamosite.

At the highest wavelengths (over $2200 \mathrm{~nm}$ ), Bishop et al. (2008) find the triplet 2250/2290/2330 nm for clinochlore), or 2260/2310/2360 nm for chamosite). Recently, Mathian et al. (2018) indicate four bands in clinochlore (2247, 2296, 2326, and $2393 \mathrm{~nm}$ ), and 
only two in chamosite (2259 and $2351 \mathrm{~nm}$ ), with a third one (weak, not measured) between these two bands.

In our sample, the main two bands of this complex absorption band centred around 2300 $\mathrm{nm}$ show a shift towards higher wavelengths from clinochlore to chamosite, with the highest values measured for red chamosite (2270 and $2370 \mathrm{~nm})$.

Relatively to the general characteristics of the visible spectrum of the member of the clinochlore-chamosite series, that of red chamosite presents two peculiarities: a weak $\mathrm{Fe}^{3+}$ absorption band indicative of the very low content of this ion, and the presence of a broad band centered around $550 \mathrm{~nm}$. Alone, this last band would induce a pink to purple color. Combined with the underlying continuum rising towards the UV, it is responsible for the orangey red colour of this chamosite variety. From Fig. 5 the absorption coefficient of the 550 $\mathrm{nm}$ band can be estimated to be about 1 absorbance unit for a thickness of $30 \mu \mathrm{m}$, that leads to an approximate value of $30 \mathrm{~A} / \mathrm{mm}$, which is considerable. This means that the absorber is very efficient.

\section{Origin of the colour of red chamosite}

The colour of minerals is a complex problem, governed by various physical-chemical factors (Fritsch \& Rossman, 1987). Many coloured varieties of nominally colourless minerals are related to the presence of a small number of elements, often from the first series of transition metals. They may absorb in the visible range due to electronic transitions within their orbitals (d-d, or crystal field (CF) transitions), or due to electronic transitions beteween two atoms, called intervalence charge transfer (IVCT) transitions. Finally, in some cases, absorption is due to colour centres, often linked to natural radiation damage. Other causes of colour in minerals are not directly related to absorption, and are thus irrelevant here. 
The key facts to be remembered for the interpretation of the visible absorption data is that the colour-causing band centered about $550 \mathrm{~nm}$, is quite wide $\left(\Delta v_{1 / 2} \sim 3700 \mathrm{~cm}^{-1}\right)$, very strongly absorbing (approx. $30 \mathrm{~A} / \mathrm{mm}$ ), and very strongly pleochroic (near-white or nearcolorless to a dark colour). In addition, it appears linked to vanadium.

For the following discussion, one must have in mind that the hydrothermal process that generated red chamosite is governed by a redox mechanism (see the introduction). It would allow for a higher oxidation state among cations of transition elements present in chamosite.

Role of vanadium enrichment. EPMA results clearly indicate that red chamosite presents a vanadium enrichment relatively to primitive chamosite, while there is no positive correlation with Mn and Ti contents, always very low. As proposed by Gloaguen et al. (2007), such a V enrichment can be explained without an external source, if one considers that the volume of neoformed chamosite is minor relatively to that of dissolved primitive chamosite: as the main part of iron from this primitive chamosite re-precipitates as pyrite, there will be a relative residual $\mathrm{V}$ enrichment, which leads to an increase of the $\mathrm{V} / \mathrm{Fe}$ ratio of neoformed chamosite.

Table 2 shows that $\mathrm{V}$ content of hydrothermal green chamosite may be as high as that of the red variety (compare No 5 and 6 of Table 2a). Thus, the presence of vanadium in chamosite appears as a necessary, but not a sufficient condition for the formation of the red variety. This is confirmed by Whitney \& Northrop (1986), who have described a vanadiumrich chlorite of (normal) green colour, where vanadium, mainly trivalent, is concentrated in octahedral sites of the brucite-type sheet. In similar samples, Meunier (1994) considers only $\mathrm{V}^{3+}$, which substitutes $\mathrm{Al}$ in octahedral sheets.

In another deposit, a mineral similar to red chlorite has been described by Mellini et al. (1991). But its TEM study revealed a close intergrowth of chlorite with biotite or hematite. Here the red colour is mainly due to $\mathrm{Fe}^{3+}$ of hematite, which presents two absorption bands at 12000 and $16000 \mathrm{~cm}^{-1}$ (Platonov, 1976), lacking in red chamosite. 
Oxidation state of vanadium. In Saint-Aubin, the dispersion of red chamosite within the oolitic ore and its low vanadium content precludes up to now to certify the oxidation state(s) of vanadium through physical methods. Oxidation states +2 and +5 can be exclude for $V$ because $\mathrm{V}^{2+}$ prevails only in strongly reducing conditions (below the iron/wüstite buffer), while $\mathrm{V}^{5+}$ implies high $\mathrm{f}\left(\mathrm{O}_{2}\right)$ (Papike et al., 2016). In aqueous system (normal conditions - $\mathrm{pH}$ neutral to acid), at low $\mathrm{Eh}, \mathrm{V}^{3+}$ (solid or aqueous species) is the stable oxidation state (Takeno, 2005; Povar et al., 2019), which coexists with $\mathrm{Fe}^{2+} . \mathrm{V}^{4+}$ species appear at higher Eh always in the stability field of $\mathrm{Fe}^{2+}$ (Takeno, 2005). According to Takeno (2005), in the same conditions, $\mathrm{Mn}^{2+}$ is the only stable oxidation state of manganese. $\mathrm{Mn}^{3+}$ appears at basic $\mathrm{pH}$, $\mathrm{Mn}^{4+}$ at high Eh.

In Saint-Aubin, abundant organic matter will favor $\mathrm{V}^{3+}$ in chamosite, as in vanadium mica roscoelite, $\mathrm{KV}_{2} \mathrm{AlSi}_{3} \mathrm{O}_{10}(\mathrm{OH})_{2}$. In red chamosite, the weak band at $620 \mathrm{~nm}$ has been tentatively related to $\mathrm{V}^{3+}$. Oxidation process related to hydrothermal stages may have stabilized, at less partly, $\mathrm{V}^{4+}$ oxidation state.

In similar geological environments with reducing conditions (graphite-bearing metamorphic series), only $\mathrm{V}^{3+}$ and $\mathrm{V}^{4+}$ have been detected: in tanzanite, a vanadium-bearing variety of zoisite, $\mathrm{Ca}_{2} \mathrm{Al}_{3}\left(\mathrm{Si}_{2} \mathrm{O}_{7}\right)\left(\mathrm{SiO}_{4}\right) \mathrm{O}(\mathrm{OH})$, from Merelani, NE Tanzania (Olivier, 2006), as well as in vanadium-rich oxide minerals of the Green Giant vanadium-graphite deposit, SW Madagascar (Di Cecco et al., 2018). In Kola region (Russia), various vanadium minerals contain exclusively $\mathrm{V}^{3+}$ (Kompanchenko et al., 2018).

If the colour is linked to vanadium, then one may compare it to that of various vanadium compounds.

Colour of vanadium oxides and silicates. Evans \& White (1987) reviewed the colour of vanadium minerals. In vanadium oxides, without the influence of other transition metals, which may induce CF or IVCT transitions, the colour is controlled by the oxidation state of 
vanadium. With $\mathrm{V}^{5+}$ (no $4 \mathrm{~s}$ and $3 \mathrm{~d}$ valence electrons), minerals are uncoloured or weakly absorbant. Oxides and hydrates of $\mathrm{V}^{4+}$ are green (i.e. haradaite, $\operatorname{Sr}(\mathrm{VO})\left(\mathrm{SiO}_{3}\right)_{2}$ ) or blue (i.e. pentagonite, $\left.\mathrm{Ca}(\mathrm{VO})\left(\mathrm{Si}_{4} \mathrm{O}_{10}\right) \cdot 4 \mathrm{H}_{2} \mathrm{O}\right) ; \mathrm{V}^{3+}$ oxides and silicates are black (for instance karelianite, $\left.\mathrm{V}_{2} \mathrm{O}_{3}\right)$ or strongly absorbent. Fe-free roscoelite $\mathrm{K}\left(\mathrm{V}^{3+}, \mathrm{Al}\right)_{2}\left(\mathrm{AlSi}_{3} \mathrm{O}_{10}\right)(\mathrm{OH})_{2}$, a muscovite isotype, is green (Ito, 1965).

When substituting as traces or minor component in oxides, $\mathrm{V}^{4+}$ gives a green colour, as in malayaite, $\mathrm{CaSnSiO}_{5}$, where $\mathrm{V}^{4+}$ replaces $\mathrm{Sn}^{4+}$ (Joo \& Lee, 2010). $\mathrm{V}^{3+}$ also gives a green colour in beryl (V-rich emerald), as well as in muscovite (Uher et al., 2008; Ertl et al., 2019), and a number of other minerals and gems (Fritsch \& Rossman, 1987).

In the general review of the colour of minerals by Platonov (1976), only tanzanite, a blue to violet vanadium-bearing variety of zoisite $\mathrm{Ca}_{2} \mathrm{Al}_{3}\left(\mathrm{Si}_{2} \mathrm{O}_{7}\right)\left(\mathrm{SiO}_{4}\right) \mathrm{O}(\mathrm{OH})$ (Faye \& Nickel, 1971), shows an absorption band (around $555 \mathrm{~nm}$ ) close to, but distinct from the specific band of red chamosite at $550 \mathrm{~nm}$ (Fig. 5). In all the studies we reviewed, there is not a single example of a vanadium mineral with a red colour strictly due to vanadium. Thus, the possibility of the $550 \mathrm{~nm}$ band originating from isolated $\mathrm{V}^{3+}$ or $\mathrm{V}^{4+}$ is eliminated.

Role of other elements. Other isolated transition metal ions can be eliminated as well. In general, those produce less absorbing, narrower bands, also less pleochroic. The absorption of iron ions has been discussed earlier, and they do not have a band at $550 \mathrm{~nm}$. Of other transition metals, only Mn and Ti are present in detectable amounts. Manganese, although a common coloring agent in minerals, can be ruled out: as $\mathrm{Mn}^{2+}$, it is so weakly absorbing that it needs to be present at several wt $\%$ element concentrations (indeed in nominal manganese minerals) to give a pink to red colour, and its concentration is quite small in Saint Aubin chamosite. In addition, according to Takeno (2005) in the conditions prevailing at St Aubin, $\mathrm{Mn}^{2+}$ is the only stable oxidation state of manganese. Thus, we do not expect to detect the absorption of $\mathrm{Mn}^{3+}$, although it is a far more efficient absorber, but this valence is either the 
result of natural irradiation (and there are no traces of irradiation in Saint-Aubin minerals), or of basic $\mathrm{pH}$ (Takeno, 2005), which do not correspond to the environment characterized for red chamosite. Similarly, for Ti, efficient coloration in minerals are obtained only through $\mathrm{Ti}^{3+}$, which is also a product of natural irradiation, absent here, or very reducing conditions (such as meteorites), which do not correspond to the redox conditions at the time of deposition. So, isolated metal ions can be eliminated as the potential cause of the red colour in our chamosite.

Colour centres absorb rarely as strongly as the $550 \mathrm{~nm}$ band. They may be strongly pleochroic, for example when the colour centre itself is a planar molecular ion (such as $\mathrm{CO}_{3}{ }^{-}$ in beryl for example - Fritsch \& Rossman, 1988), Thus, combined, again, with the absence of irradiation, colour centers are very unlikely cause of this absorption.

Thus, only charge transfer (IVCT) processes offer the observed combination of extremely efficient absorption, very strong pleochroism and rather broad bands (Mattson \& Rossman, 1987) required to explain the results of this study.

Charge-transfer mechanism. Examples of IVCT include mostly $\mathrm{Fe}^{2+}-\mathrm{Fe}^{3+}$ in a variety of minerals, such as beryl, cordierite, and lazulite (Fritsch \& Rossman, 1988). Furthermore, here, the pleochroism is particularly intense, going from near colorless to a very dark color, as is the case for many charge transfer processes (as the three examples cited before). Thus, the exceptionally strong pleochroism, combined with the exceptionally large absorption coefficient, strongly support the IVCT working hypothesis, which is the only type of absorption mechanism to which those two properties are typically associated.

The large width of the $550 \mathrm{~nm}$ absorption band (Fig. 5) is an additional argument. Even though the value of $\Delta v_{1 / 2}\left(\sim 3700 \mathrm{~cm}^{-1}\right)$ may appear relatively low relatively to the common interval 5000-6300 $\mathrm{cm}^{-1}$ indicated by Mattson \& Rossman (1987) for $\mathrm{Fe}^{2+} / \mathrm{Fe}^{3+}$ IVCT, it is in accordance with the lowest values 3150 and $3575 \mathrm{~cm}^{-1}$ indicated by these authors for biotite and chlorite, respectively. 
According to EPMA results and the spectroscopic study, only the pair $\mathrm{Fe} / \mathrm{V}$ can be considered for such an IVCT $\|(001)$. A heteronuclear charge transfer between two cations M1 and M2 in adjacent octahedra, with oxidation states $\mathrm{m}+$ and $\mathrm{n}+$, respectively, corresponds to the general formula $\mathrm{M} 1^{\mathrm{m}+}+\mathrm{M} 2^{\mathrm{n}+} \rightarrow \mathrm{M} 1^{(\mathrm{m}-1)+}+\mathrm{M} 2^{(\mathrm{n}+1)+}(4)$.

In addition, $\mathrm{Fe}^{3+}$ is minor relatively to $\mathrm{Fe}^{2+}$, as indicated by the weak absorption band at $710 \mathrm{~nm}$ in Vis-NIR spectra (Fig. 5), which would correspond to $\mathrm{Fe}^{2+} / \mathrm{Fe}^{3+}$ IVCT. Two solutions are possible for formula (4):

$\mathrm{Fe}^{3+}+\mathrm{V}^{3+} \rightarrow \mathrm{Fe}^{2+}+\mathrm{V}^{4+}(5)$, or inversely $\mathrm{V}^{4+}+\mathrm{Fe}^{2+} \rightarrow \mathrm{V}^{3+}+\mathrm{Fe}^{3+}(6)$

IVCT according to formula (5), which implies the presence of $\mathrm{Fe}^{3+}$ and $\mathrm{V}^{3+}$ in adjacent octahedra, both with a low concentration in chamosite, is less probable than IVCT (6), as there will always be a $\mathrm{Fe}^{2+}$ ion adjacent to any V-containing octahedron. IVCT (6) appears as the best proposal to explain the broad absorption band around $550 \mathrm{~nm}$.

Up to now, such a $\mathrm{Fe}^{2+}-\mathrm{V}^{4+} \rightarrow \mathrm{Fe}^{3+}-\mathrm{V}^{3+}$ IVCT has not been documented. It would be similar to the $\mathrm{Fe}^{2+} / \mathrm{Ti}^{4+}$ IVCT described in dumortierite and other $(\mathrm{Fe}, \mathrm{Ti})$-bearing silicates (Platonov et al., 2000, and references herein). Nevertheless, in the case of dumortierite, Fe and $\mathrm{Ti}$ are in face-sharing octahedra with a short Fe-Ti distance with direct overlapping of $T_{2 g}$ levels. In edge-sharing octahedra, there must be an indirect charge transfer via bridging oxygen.

Resulting colour. Reconsidering spectroscopic data in the visible range according to IVCT mechanism, the red colour of chamosite is the sum of two opposite spectroscopic characteristics, 1) An absorption band due to Fe/V IVCT, which absorbs the green colour, owing to minor vanadium, and 2) A good transparency in the orange-red part of the spectrum, due to very low $\mathrm{Fe}^{3+}$. This transparency is a rather special characteristic because, generally, chlorite presents significant $\mathrm{Fe}^{3+}$ content which will induce an absorption band around $700 \mathrm{~nm}$ $\left(\mathrm{Fe}^{2+} / \mathrm{Fe}^{3+} \mathrm{IVCT}\right)$. 


\section{Oxidation conditions}

In Saint-Aubin, the sulfidation of the oolitic iron ore is the result of a geochemical process combining siderite leaching and redox reaction between organic matter and hydrothermal solution (Gloaguen et al., 2007). This organic matter acted as a buffer to control strong reducing conditions as long as it was in close contact with the hydrothermal solution. It allowed the crystallization of green chamosite. Inversely, when locally this buffer was not operating, the hydrothermal solution induced a weak increase of $\mathrm{f}\left(\mathrm{O}_{2}\right)$, and the crystallization of red chamosite.

Formation of red chamosite would be the result of the strongest interaction of the oxidant hydrothermal solution with primitive oolitic ore, according to the preferred location of red chlorite in the strongest reaction zones (alteration haloes) between massive sulphides lenses and oolitic ironstone. Around these zones, chamosite may have crystallized at the same time with similar vanadium contents, but with a normal green colour. The formation of brown berthierine would obey to similar increase of $\mathrm{f}\left(\mathrm{O}_{2}\right)$ during the late, low-temperature hydrothermal stage.

\section{CONCLUSIONS}

In Saint-Aubin-des-Châteaux, the interaction between the primitive lower Ordovician oolitic iron ore and an early Variscan hydrothermal solutions lead to a complex paragenetic sequence, illustrated by the chemical evolution of chamosite. Together with its ${ }^{\mathrm{IV}} \mathrm{Al}$ content, vanadium concentration is the best mark of this evolution, with the highest values related to the maximal hydrothermal remobilization of the oolitic ore at the beginning of the process. It 
leads to the formation of a red variety of chamosite, related to a local increase of $\mathrm{f}\left(\mathrm{O}_{2}\right)$ when the primitive organic matter did not act locally as a buffer of reducing conditions.

As a whole, the chamosite composition field from Saint-Aubin fills the gap between the solid-solution field of IIb polytype in natural compounds defined by Brown \& Bailey (1962) and synthetic Mg-free chamosite (Parra et al., 2005). While its $\mathrm{Fe} /(\mathrm{Fe}+\mathrm{Mg}$ ) ratio is quite stable, its ${ }^{\mathrm{IV}} \mathrm{Al}$ content varies significantly from 1.4 up to 1.8 atom per four tetrahedra, according to variations of $\mathrm{SiO}_{2}$ local activity. Red chamosite has $\mathrm{Fe} /(\mathrm{Fe}+\mathrm{Mg})$ mean ratio close to 0.944 , and that of ${ }^{\mathrm{IV}} \mathrm{Al}$ close to 1.67 at.

Taking into account microprobe analyses of $\mathrm{Mg}$-poor natural as well as $\mathrm{Mg}$-free synthetic samples (Fig. 6), the simplified composition of chamosite (Fe-pure, no vacancies) agrees with the non-stoichiometric formula $\left(\mathrm{Fe}_{5-\mathrm{x}} \mathrm{Al}_{1+\mathrm{x}}\right)\left(\mathrm{Si}_{3-\mathrm{x}} \mathrm{Al}_{1+\mathrm{x}}\right) \mathrm{O}_{10}(\mathrm{OH})_{8}$, with $0.2<x<0.8$. Stoichiometric formulas $\left(\mathrm{Fe}_{4} \mathrm{Al}_{2}\right)\left(\mathrm{Si}_{2} \mathrm{Al}_{2}\right) \mathrm{O}_{10}(\mathrm{OH})_{8}$ and $\left(\mathrm{Fe}_{5} \mathrm{Al}\right)\left(\mathrm{Si}_{3} \mathrm{Al}\right) \mathrm{O}_{10}(\mathrm{OH})_{8}$, commonly used as theoretical end-members (so-called "Fe-amesite" and "daphnite", respectively) for thermodynamic calculations (Parra et al., 2005 ; Bourdelle et al., 2013) are outside this solid solution, and would be unstable.

According to the absorption spectrum in the Vis-NIR range, the colour and exceptionally strong pleochroism of red chamosite are explained by the combination of two circumstances. On one hand, the proposed IVCT mechanism between vanadium and iron in trioctahedral sheet (probably $\mathrm{Fe}^{3+}-\mathrm{V}^{3+} \rightarrow \mathrm{Fe}^{2+}-\mathrm{V}^{4+} \mathrm{CT}$ ) absorbs the green. On the other hand, the low $\mathrm{Fe}^{3+}$ content precludes significant ${ }^{\mathrm{VI}} \mathrm{Fe}^{2+} /{ }^{\mathrm{VI}} \mathrm{Fe}^{3+}$ IVCT and favours red transparency.

In order to check this model of Fe/V IVCT, it would be useful to perform Vis-NIR spectroscopic studies on other vanadiferous green chlorites, as those from Utah (Whitney \& Northrop, 1986). According to the proposed model, such a green colour may be due either to the association of two absorption bands at 550 and $700 \mathrm{~nm}\left(\mathrm{Fe}^{2+} / \mathrm{V}^{4+}\right.$ and $\mathrm{Fe}^{2+} / \mathrm{Fe}^{3+}$ IVCT, respectively), or to the lack thereof (only $\mathrm{Fe}^{2+}$ and $\mathrm{V}^{3+}$ ). 
The oolitic iron ore deposit of Saint-Aubin-des-Châteaux is an original example of the succession of numerous Mg-poor chamosite generations, from primitive weak metamorphic to several hydrothermal varieties. Crystal chemical changes ( ${ }^{\mathrm{IV}} \mathrm{Al}$ and minor vanadium contents) as well as colour change of chamosite are controlled by the evolution of the geochemistry of the system (Al/Si ratio; redox conditions; chemical exchanges between primitive oolitic ore and hydrothermal solution).

\section{ACKNOWLEDGEMENTS}

We sincerely thank Dr. A. Meerschaut (CNRS-IMN, retired), who performed X-ray single crystal examination of red chamosite. Dr. G. Cornen (LPG, Nantes university and CNRS - retired) kindly informed us on his first observations of red chamosite. Discussion with V. Trincal (Paul Sabatier University, Toulouse) was very helpful. The careful examination performed by Peter C. Ryan (Middlebury College, Vermont, USA), Associate Editor Javier Cuadros, and an anonymous reviewer greatly improved the quality of the manuscript. 


\section{REFERENCES}

Bailey S.W. (1980) Structures of layer silicates. Pp. 1-125 in: Crystal Structures of Clay Minerals and their X-ray Identification (G.W. Brindley \& G. Brown, editors), Monograph 5, Chapter 1, The Mineralogical Society of Great Britain and Ireland, London.

Bailey S.W. (1988) Chlorite structure and crystal chemistry. Pp. 347-403 in: Hydrous Phyllosilicates (exclusive of mica) (S.W. Bailey, editor), Reviews in mineralogy 19, Mineralogical Society of America, Washington D.C.

Bannister F.A. \& Whittard W.F. (1945) A magnesian chamosite from the Wenlock Limestone of Wickwar, Gloucestershire. The Mineralogical Magazine, 27, No 190, 99-111.

Bayliss P. (1975) Nomenclature of the trioctahedral chlorites. The Canadian Mineralogist, 13, $178-180$.

Bishop J.L., Lane M.D., Dyar M.D., Brown A.J. (2008) Reflectance and emission spectroscopy study of four groups of phyllosilicates: smectites, kaolinite-serpentines, chlorites and micas. Clay Minerals, 43, 35-54.

Bourdelle F., Parra T., Chopin C. \& Beyssac O. (2013) A new chlorite geothermometer for diagenetic to low-grade metamorphic conditions. Contribution to Mineralogy and Petrology, 165, 723-735. 
Brindley G.W. (1980) Order-disorder in clay mineral structures. Pp. 125-196 in: Crystal Structures of Clay Minerals and their X-ray Identification (G.W. Brindley \& G. Brown, editors), Monograph 5, Chapter 2, The Mineralogical Society of Great Britain and Ireland, London.

Brown B.E. \& Bailey J.F. (1962) Chorite polytypism: I. Regular and semi-random one-layer structures. The American Mineralogist, 47, 819-850.

Capitani G.C., Schingaro E., Lacalamita M., Mesto E. \& Scordari F. (2016) Structural anomalies in tobelite-2M2 explained by high resolution and analytical electron microscopy. The Mineralogical Magazine, 80, 143-156.

Chauvel J.-J. (1971) Contribution à l'étude des minerais de fer de l'Ordovicien inférieur de Bretagne. Mémoires de la Société géologique et minéralogique de Bretagne, 16, 244 pp.

Chauvel J.-J. (1974) Les minerais de fer de l'Ordovicien inférieur du bassin de BretagneAnjou, France. Sedimentology, 21, 127-147.

Criddle A.J. (1990) Microscope-photometry, reflectance measurement, and quantitative color. Pp. 135-169 in: Advanced Microscopic Studies of Ore Minerals (J.L. Jambor \& D.J. Vaughan, editors), Short Course Handbook, 17, Mineralogical Association of Canada, Ottawa.

Dabard M.-P. (1983) Etude pétrographique et géochimique des roches sédimentaires paléozö̈ques du Massif Armoricain : Presqu'île de Crozon, flanc nord du bassin de 
Laval. Thesis, Rennes I University, 207 pp.

Delaloye M.F. \& Odin G.S. (1988) Chamosite, the green marine clay from Chamoson; a study of Swiss oolitic ironstones. Pp. 7-28 in: Green Marine Clays: Oolitic Ironstone Facies, Verdine Facies, Glaucony Facies and Celadonite-bearing Facies - A Comparative Study (G. S. Odin, editor), Elsevier.

Di Cecco V.E., Tait K.T., Spooner E.T.C. \& Scherba C. (2018) The vanadium-bearing oxide minerals of the Green Giant vanadium-graphite deposit, southwest Madagascar. The Canadian Mineralogist, 56, 247-257.

Ertl A., Rakovan J., Hugues J.M., Bernhardt H.-J. \& Rossman G.R. (2019) Vanadium-rich muscovite from Austria: Crystal structure, chemical analysis, and spectroscopic investigations. The Canadian Mineralogist, 57, 383-389.

Evans H.T. \& White J.S. (1987) The colorful vanadium minerals: A brief review and a new classification. The Mineralogical Record, 18, 333-340.

Faye G.H. (1968) The optical absorption spectra of iron in six-coordinate sites in chlorite, biotite, phlogopite and vivianite. The Canadian Mineralogist, 9, 403-425.

Faye G.H. \& Nickel E.H. (1971) On the pleochroism of vanadium-bearing zoisite from Tanzania. The Canadian Mineralogist, 10, 812-821.

Fernandez A. \& Moro M.C. (1996) Chemical aspects of the magnetite and chlorite from 
Ordovician ironstones of the Zamora province (Spain). Geogaceta, 20, 1531-1534.

Fernandez A., Chauvel J.-J. \& Moro M.C. (1998) Comparative study of the Lower Ordovician ironstones of the Iberian Massif (Zamora, Spain) and of the Armorican Massif (Central Brittany, France). Journal of Sedimentary Research, Section A, 68, 53-62.

Ferrage E., Martin F., Micoud P., Petit S., de Parseval P., Beziat D. \& Ferret J. (2003) Cation site distribution in clinochlores: a NIR approach. Clay Minerals, 38, 329-338.

Fritsch E. \& Rossman G.R. (1987) An update on color in gems. Part I: Introduction and colors caused by dispersed metal ions. Gems \& Gemmology, 23, 126-139.

Fritsch E. \& Rossman G.R. (1988) An update on color in gems. Part II: Colors involving multiple atoms and color centers. Gems \& Gemmology, 24, 3-15.

Gloaguen E., Branquet Y., Boulvais P., Moëlo Y., Chauvel J.-J., Chiappero P.-J. \& Marcoux E. (2007) Palaeozoic oolitic ironstone of the French Armorican Massif: a chemical and structural trap for orogenic base metal-As-Sb-Au mineralization during Hercynian strike-slip deformation. Mineralium Deposita, 42, 399-422.

Gresens R.L. \& Stensrud H.L. (1977) More data on red muscovite. American Mineralogist, 62, 1245-1251.

Hey M.H. (1954) A new review of the chlorites. The Mineralogical Magazine, 30, No 224, 277-291. 
Hillier S. \& Velde B. (1991) Octahedral occupancy and the chemical composition of diagenetic (low-temperature) chlorites. Clay Minerals, 26, 149-168.

Hurlbut C.S. (1969) Gem zoisite from Tanzania. American Mineralogist, 54, 702-709.

Inoué S. \& Kogure T. (2016) High-resolution transmission electron microscopy (HRTEM) study of stacking irregularity in Fe-rich chlorite from selected hydrothermal ore deposits. Clays \& Clay Minerals, 64, 131-144.

Ito J. (1965) Synthesis of vanadium silicates: Haradaite, goldmanite and roscoelite. Mineralogical Journal, 4, 299-316.

Jiang W.-T., Peacor D.R. \& Buseck P.R. (1994) Chlorite geothermometry? - Contamination, and apparent octahedral vacancies. Clays \& Clay Minerals, 42, 593-605.

Jiang W.-T., Peacor D.R. \& Slack J.F. (1992) Microstructures, mixed layering, and polymorphism of chlorite and retrograde berthierine in the Kidd Creek massive sulfide deposit, Ontario. Clays \& Clay Minerals, 40, 501-514.

Joo I.-D. \& Lee B.-H. (2010) Effect of V-doping on colour and crystallization of malayaite pigments. Journal of the Korean Ceramic Society, 47, 302-307.

Kompanchenko A.A., Voloshin A.V. \& Balagansky V.V. (2018) Vanadium mineralization in the Kola region, Fennoscandian Shield. Minerals, 8-474, 20 p. 
Langer K., Tillmans E., Kersten M., Almen H. \& Arni R.K. (2002) The crystal chemistry of $\mathrm{Mn}^{3+}$ in the clino- and ortho-zoisite structure types, $\mathrm{Ca}_{2} \mathrm{M}_{3}{ }^{3+}\left[\mathrm{OH}|\mathrm{O}| \mathrm{SiO}_{4} \mid \mathrm{Si}_{2} \mathrm{O}_{7}\right]: \mathrm{A}$ structural and spectroscopic study of some natural piemontites and "thulites" and their synthetic equivalents. Zeitschrift für Kristallographie, 217, 563-580.

Leach D.L., Taylor R.D., Fey, D.L., Diehl, S.F. \& Saltus, R.W. (2010) A deposit model for Mississipi Valley-type lead-zinc ores. In Mineral deposit models for resource assessment, USGS Scientific Investigation Reports 2010-5070-A, 52 p.

Mathian M., Hebert B., Baron F., Petit S., Lescuyer J.-L., Furic R. \& Beaufort D. (2018) Identifying the phyllosilicates of hypogene ore deposits in lateritic saprolites using the near-IR vspectroscopy second derivative methodology. Journal of Geochemical Exploration, 186, 298-314.

Mattson S.M. \& Rossman G.R. (1987) Identifying characteristics of charge transfer transitions in minerals. Physics and Chemistry of Minerals, 14, 94-99.

McOnie A.W., Fawcett J.J. \& James R.S. (1975) The stability of intermediate chlorites of the clinochlore-daphnite series at $2 \mathrm{Kbar} P \mathrm{P}_{2} \mathrm{O}$. The American Mineralogist, 60, 10471062.

Mellini M., Nieto F., Alvarez F. \& Gomez-Pugnaire M.-T. (1991) Mica-chlorite intermixing and altered chlorite from the Nevado-Filabride micaschists, Southern Spain. European Journal of Mineralogy, 3, 27-38. 
Mesto E, Scordari F, Lacalamita M \& Schingaro E (2012) Tobelite and $\mathrm{NH}_{4}{ }^{+}$-rich muscovite single crystals from Ordovician Armorican sandstones (Brittany, France): structure and crystal chemistry. American Mineralogist, 97, 1460-1468.

Meunier J.D. (1994) The composition and origin of vanadium-rich clay minerals in Colorado Plateau Jurassic sandstones. Clays \& Clay Minerals, 42, 391-401.

Moëlo Y., Gloaguen E., Lulzac, Y. \& Le Roch P. (2006) Minéralogie du gisement de SaintAubin-des-Châteaux (Loire-Atlantique). Cahier des Micromonteurs, 91, 3-25.

Moëlo Y., Lasnier B., Palvadeau P., Léone P. \& Fontan F. (2000) La lulzacite, $\mathrm{Sr}_{2} \mathrm{Fe}^{2+}\left(\mathrm{Fe}^{2+}, \mathrm{Mg}\right)_{2} \mathrm{Al}_{4}\left(\mathrm{PO}_{4}\right)_{4}(\mathrm{OH})_{10}$, un nouveau phosphate de strontium (Saint-Aubindes-Châteaux, Loire-Atlantique, France). Comptes Rendus de l'Académie des Sciences, Sciences de la Terre et des Planètes, 330, 317-324.

Moëlo Y., Léone P., Matsushita Y., Mancini-Legranvalet M. \& Deniard P. (2009) Berthiérine hydrothermale de Saint-Aubin-des-Châteaux (Loire-Atlantique). $7^{\text {th }}$ meeting, Groupe Français des Argiles, Toulouse, 14-16 April (abstract).

Moëlo Y., Lulzac Y., Rouer O., Palvadeau P., Gloaguen E. \& Léone P. (2002) Pretulite with Sc-bearing zircon and xenotime from a paleozoic sedimentary iron ore (Saint-Aubindes-Châteaux, Armorican Massif, France). The Canadian Mineralogist, 40, 1657-1673.

Moëlo Y., Rouer O. \& Bouhnik-Le Coz M. (2008) From diagenesis to hydrothermal 
recrystallization: Mineralogy and chemistry of polygenic Sr-rich fluorapatite from the oolitic ironstone of Saint-Aubin-des-Châteaux (Armorican Massif, France). European Journal of Mineralogy, 20, 205-216.

Mücke A. (2006) Chamosite, siderite and the environmental conditions of their formation in chamosite-type Phanerozoic ooidal ironstones. Ore Geology Reviews, 28, 235-249.

Novak F., Velensky J., Losert J., Kupka F. \& Valcha Z. (1959) Orthochamosite, a new mineral from hydrothermal ore veins of Kank near Kutna Hora (Kuttenberg), Czechoslovakia. Geologie (Berlin), 8, 159-167.

Olivier B. (2006) The geology and petrology of the Merelani tanzanite deposit, NE Tanzania. Ph. D., University of Stellenbosch, South Africa, 322 pp.

Orcel J. (1923) Sur la bavalite de Bas-Vallon. Comptes Rendus de l'Académie des Sciences, 177, 271-273.

Oversluizen G. \& Metselaar R. (1982) ESR and optical absorption spectra of reduced vanadium ions in $\mathrm{Ca}_{2} \mathrm{NaMg}_{2} \mathrm{~V}_{3} \mathrm{O}_{12}$ garnet. Journal of Physics $C$ : Solid State Physics, 15, 4869-4880.

Papike J.J., Simo S.B., Burge P.V., Bell A.S., Shearer C.K. \& Karner J.M. (2016) Chromium, vanadium, and titanium valence systematics in solar system pyroxene as a recorder of oxygen fugacity, planetary provenance, and processes. The American Mineralogist, 101, 907-918. 
Parra T., Vidal O. \& Theye T. (2005): Experimental data on the Tschermak substitution in Fe-chlorite. The American Mineralogist, 90, 359-370.

Platonov A.N. (1976) The nature of the colour of minerals. Naukova Dumka ed., Kiev, 264 pp. (in Russian).

Platonov A.N., Langer K., Chopin C., Andrut M. \& Taran N. (2000) $\mathrm{Fe}^{2+}-\mathrm{Ti}^{4+}$ chargetransfer in dumortierite. European Journal of Mineralogy, 12, 521-528.

Pochon A., Gapais D., Gloaguen E., Gumiaux C., Branquet Y., Cagnard F. \& Martelet G. (2016a) Antimony deposits in the Variscan Armorican belt, a link with mafic intrusives? Terra Nova, 28, 138-145.

Pochon A., Poujol M., Gloaguen E., Branquet Y., Cagnard F., Gumiaux C. \& Gapais D. (2016b) U-Pb LA-ICP-MS dating of apatite in mafic rocks: Evidence for a major magmatic event at the Devonian-Carboniferous boundary in the Armorican Massif (France). The American Mineralogist, 101, 2430-2442.

Pochon A., Beaudoin G., Branquet Y., Boulvais P., Gloaguen E. \& Gapais D. (2017) Metal mobility during hydrothermal breakdown of Fe-Ti oxides: Insights from $\mathrm{Sb}-\mathrm{Au}$ mineralizing event (Variscan Armorican Massif, France). Ore Geology Reviews, 91, 66-99.

Pochon A., Gloaguen E., Branquet Y., Poujol M., Ruffet G., Boiron M.-C., Boulvais P., 
Gumiaux C., Cagnard F., Gouazou F. \& Gapais D. (2018) Variscan Sb-Au mineralization in Central Brittany (France): A new metallogenic model derived from the Le Semnon district. Ore Geology Reviews, 97, 109-142.

Pochon A., Branquet Y., Gloaguen E., Ruffet G., Poujol M., Boulvais P., Gumiaux C., Cagnard F., Baele J.-M., Kéré I. \& Gapais D. (2019) A Sb \pm Au mineralizing peak at $360 \mathrm{Ma}$ in the Variscan belt. BSGF - Earth Sci. Bull., 190, 4.

Povar I., Spinu O., Zinicovscaia I., Pintile B. \& Ubaldini S. (2019) Revised Pourbaix diagrams for the vanadium-water system. Journal of Electrochemical Science and Engineering, 9, 75-84.

Richardson S.M. \& Richardson J.W. (1982) Crystal structure of a pink muscovite from Archer's Post, Kenya: implications for reverse pleochroism in dioctahedral micas. American Mineralogist, 67, 69-75.

Rule A.C. \& Bailey S.W. (1987) Refinement of the crystal structure of a monoclinic ferroan clinochlore. Clays \& Clay Minerals, 35, 129-138.

Shau Y.-H. \& Peacor D.R. (1992) Phyllosilicates in hydrothermally altered basalts from DSDP Hole 504B, Leg 83 - a TEM and AEM study. Contributions to Mineralogy and Petrology, 112, 119-133.

Shirozu H. \& Bailey S.W. (1965) Chlorite polytypism: III. Crystal structure of an orthohexagonal iron chlorite. American Mineralogist, 50, 868-885. 
Smyth J.R., Darby Dyar M., May H.M., Bricker O.P. \& Acker J.G. (1997) Crystal structure refinement and Mössbauer spectroscopy of an ordered triclinic clinochlore. Clays \& Clay Minerals, 45, 544-550.

Takeno N. (2005) Atlas of Eh-pH Diagrams. Intercomparison of Thermodynamic Databases. Geological Survey of Japan, Open file report 419, 287 p.

Tartèse R., Poujol M., Gloaguen E., Boulvais P., Drost K., Košler J. \& Ntaflos T. (2015) Hydrothermal activity during tectonic building of the Variscan orogen recorded by U$\mathrm{Pb}$ systematics of xenotime in the Grès-Armoricain formation, Massif Armoricain, France. Mineralogy and Petrology, 109, 2468-2483.

Trincal V. \& Lanari P. (2016) Al-free di-trioctahedral substitution in chlorite and a ferrisudoite end-member. Clay Minerals, 51, 675-689.

Trincal V., Lanari P., Buatier M., Lacroix B., Charpentier D., Labaume P. \& Muňoz M. (2015) Temperature micro-mapping in oscillatory-zoned chlorite: Application to study of a green-schist facies fault zone in the Pyrenean Axial Zone (Spain). American Mineralogist, 100, 868-885.

Uher P., Kováčik M., Kubiš M., Shtukenberg A. \& Ozdín D. (2008) Metamorphic vanadianchromian silicate mineralization in carbon-rich amphibole schists from the Malé Karpaty Mountains, Western Carpathians, Slovakia. American Mineralogist, 93, 63-73. 
Vidal O., De Andrade V., Lewin E., Muñoz M., Parra T. \& Pascarelli S. (2006) P-Tdeformation- $\mathrm{Fe}^{3+} / \mathrm{Fe}^{2+}$ mapping at the thin section scale and comparison with XANES mapping: application to a garnet-bearing metapelite from the Sambagawa metamorphic belt (Japan). Journal of Metamorphic Geology, 24, 669-683.

Walker J.R. \& Bish D.L. (1992) Application of Rietveld refinement techniques to a disordered IIb Mg-chamosite. Clays \& Clay Minerals, 40, 319-322.

Whitney G. \& Northrop H.R. (1986) Vanadium chlorite from a sandstone-hosted vanadiumuranium deposit, Henry basin, Utah. Clays \& Clay Minerals, 34, 488-495.

Wiewióra A. \& Weiss Z. (1990) Crystallochemical classifications of phyllosilicates based on the unified system of projection of chemical composition: II. The chlorite group. Clay Minerals, 25, 81-92.

Zanazzi P.F., Montagnoli M., Nazzareni S. \& Comodi P. (2006) Structural effects of pressure on triclinic chlorite: a single-crystal study. American Mineralogist, 91, 1871-1878.

Zane A., Sassi R. \& Guidotti C.V. (1998) New data on metamorphic chlorite as a petrogenetic indicator mineral, with special regard to greenschist-facies rocks. The Canadian Mineralogist, 36, 713-726.

Zheng H. \& Bailey S.W. (1989) The structures of intergrown triclinic and monoclinic II-b chlorites from Kenya. Clays and Clay Minerals, 37, 308-316. 


\section{TABLE CAPTIONS}

Table 1. Different generations of chamosite in Saint-Aubin-des-Châteaux.

Table 2. Electron microprobe analysis of various chamosite generations from Saint-Aubin. a) Wt.\% oxides. b) Cation contents per $\mathrm{O}_{10}(\mathrm{OH})_{8}$.

Table 3. Absorption bands in the visible-NIR absorbance spectra [A: $\mathrm{E} \perp(001)$; $\mathrm{B}$ : $\mathrm{E} \|(001)]$ of red chamosite.

Table 4. Selected crystallographic parameters and chemical compositions of members of the clinochlore-chamosite series with well-known crystal structure.

Table 5. Structural formulas per $\mathrm{O}_{10}(\mathrm{OH})_{8}$ of natural $\mathrm{Mg}$-poor chamosites $(\mathrm{Fe} /(\mathrm{Fe}+\mathrm{Mg})>$ $0.80)$. 


\section{TABLES}

Table 1.

\begin{tabular}{|c|c|c|c|}
\hline Stage & Ore type & Ch. col. & No \\
\hline Weak metamorphic & Oolitic & green & 1 \\
\hline \multirow[t]{5}{*}{ Hydrothermal HT 1} & Oolitic+chamosite & green & 2 \\
\hline & Chamosite+pyrite & green & 3 \\
\hline & Replacement front with chamosite+apatite $*$ & red & $4-5$ \\
\hline & Replacement front with chamosite & green & 6 \\
\hline & Massive sulfide lens & red & 7 \\
\hline Hydrothermal HT 2 & Edge of sulfide vein & red & $8-11$ \\
\hline \multirow[t]{4}{*}{ Hydrothermal HT 3} & Polymetallic Quartz vein within sandstone & green & 12 \\
\hline & Quartz+Pyrite+Siderite+Lz. vein & green & 13 \\
\hline & Quartz+Tob+SFS+Au vein within sandstone & green & 14 \\
\hline & Sandstone & green & $15-16$ \\
\hline Late hydrothermal LT 4 & Retromorphosis - berthierine ${ }^{* *}$ & brown & 17 \\
\hline
\end{tabular}


Table 2a

\begin{tabular}{|cc|ccccccc|cc|}
$\mathrm{No}$ & Colour & $\mathrm{FeO}$ & $\mathrm{MnO}$ & $\mathrm{MgO}$ & $\mathrm{Al}_{2} \mathrm{O}_{3}$ & $\mathrm{~V}_{2} \mathrm{O}_{3}$ & $\mathrm{SiO}_{2}$ & $\mathrm{TiO}_{2}$ & $\mathrm{Sum}$ & $+\mathrm{H}_{2} \mathrm{O}$ \\
\hline $1^{*}$ & Green & 40.12 & 0.11 & 1.28 & 24.25 & 0.25 & 21.05 & 0.02 & 87.08 & 97.38 \\
$2^{*}$ & Green & 40.05 & 0.07 & 1.29 & 27.69 & 0.47 & 19.54 & 0.02 & 89.13 & 99.71 \\
$3^{*}$ & Green & 40.00 & 0.06 & 1.14 & 26.48 & 0.10 & 19.87 & 0.03 & 87.68 & 98.07 \\
$4 *$ & Red & 39.09 & 0.06 & 1.77 & 26.66 & 0.82 & 20.46 & 0.01 & 88.87 & 99.48 \\
5 & Red & 39.12 & 0.06 & 1.82 & 26.66 & 0.83 & 20.50 & 0.01 & 88.99 & 99.61 \\
$6^{*}$ & Green & 37.98 & 0.17 & 1.87 & 26.20 & 0.84 & 20.93 & 0.02 & 88.01 & 98.58 \\
$7 *$ & Red & 40.71 & 0.11 & 1.12 & 25.50 & 0.84 & 20.57 & 0.02 & 88.87 & 99.36 \\
$8^{*}$ & Red & 40.30 & 0.10 & 1.35 & 25.05 & 0.24 & 20.93 & 0.01 & 87.98 & 98.40 \\
9 & Red & 41.60 & 0.12 & 1.13 & 26.06 & 0.88 & 20.63 & 0.01 & 90.43 & 101.09 \\
10 & Red & 42.36 & 0.06 & 1.24 & 25.00 & 1.06 & 20.25 & 0.01 & 89.97 & 100.48 \\
11 & Red & 42.77 & 0.08 & 1.16 & 24.13 & 0.58 & 20.28 & 0.03 & 89.03 & 99.39 \\
$12 *$ & Green & 38.79 & 0.29 & 2.18 & 25.39 & 0.02 & 21.41 & 0.01 & 88.09 & 98.78 \\
13 & Green & 42.35 & 0.12 & 1.48 & 23.95 & 0.02 & 21.36 & 0.04 & 89.31 & 99.64 \\
$14 *$ & Green & 42.34 & 0.15 & 1.37 & 22.58 & 0.03 & 21.79 & 0.02 & 88.28 & 98.61 \\
15 & Green & 43.97 & 0.00 & 1.35 & 21.89 & 0.38 & 21.54 & 0.02 & 89.16 & 99.48 \\
16 & Green & 41.06 & 0.00 & 1.28 & 23.44 & 0.39 & 23.03 & 0.03 & 89.22 & 99.82 \\
$17 * *$ & Red & 41.74 & 0.01 & 1.42 & 23.59 & 0.46 & 22.94 & 0.02 & 90.18 & 100.85 \\
\hline \multirow{2}{*}{$*$ First set of analyses (Gloaguen et } & al., 2007). $* *$ Late berthierine (for comparison). \\
\hline
\end{tabular}


Table 2b.

\begin{tabular}{|cc|cccccc|ccccc|}
$\mathrm{No}$ & Colour & $\mathrm{Fe}$ & $\mathrm{Mn}$ & $\mathrm{Mg}$ & $\mathrm{Al}$ & $\mathrm{V}$ & $\mathrm{Si}$ & ${ }^{\mathrm{IV}} \mathrm{Al}$ & ${ }^{\mathrm{VI}} \mathrm{Al}$ & $\Sigma \mathrm{Me}$ & $\mathrm{Vac}$. & $\mathrm{Fe}$ rat. \\
\hline 1 & Green & 3.89 & 0.01 & 0.22 & 3.31 & 0.02 & 2.44 & 1.56 & 1.75 & 9.89 & 0.11 & 0.944 \\
2 & Green & 3.78 & 0.01 & 0.22 & 3.68 & 0.04 & 2.20 & 1.80 & 1.89 & 9.93 & 0.07 & 0.944 \\
3 & Green & 3.84 & 0.01 & 0.20 & 3.58 & 0.01 & 2.28 & 1.72 & 1.87 & 9.92 & 0.08 & 0.950 \\
4 & Red & 3.68 & 0.01 & 0.30 & 3.53 & 0.07 & 2.30 & 1.70 & 1.84 & 9.89 & 0.11 & 0.924 \\
5 & Red & 3.68 & 0.01 & 0.30 & 3.53 & 0.08 & 2.30 & 1.70 & 1.83 & 9.89 & 0.11 & 0.922 \\
6 & Green & 3.59 & 0.02 & 0.31 & 3.49 & 0.08 & 2.36 & 1.64 & 1.85 & 9.85 & 0.15 & 0.916 \\
7 & Red & 3.87 & 0.01 & 0.19 & 3.42 & 0.08 & 2.34 & 1.66 & 1.86 & 9.91 & 0.09 & 0.951 \\
8 & Red & 3.86 & 0.01 & 0.23 & 3.38 & 0.02 & 2.40 & 1.60 & 1.78 & 9.90 & 0.10 & 0.941 \\
9 & Red & 3.90 & 0.01 & 0.19 & 3.44 & 0.08 & 2.31 & 1.69 & 1.75 & 9.93 & 0.07 & 0.951 \\
10 & Red & 4.02 & 0.01 & 0.21 & 3.34 & 0.10 & 2.30 & 1.70 & 1.64 & 9.98 & 0.02 & 0.949 \\
11 & Red & 4.12 & 0.01 & 0.20 & 3.28 & 0.05 & 2.34 & 1.66 & 1.61 & 10.00 & 0.00 & 0.952 \\
12 & Green & 3.67 & 0.03 & 0.37 & 3.39 & 0.00 & 2.42 & 1.58 & 1.81 & 9.88 & 0.12 & 0.903 \\
13 & Green & 4.04 & 0.01 & 0.25 & 3.22 & 0.00 & 2.43 & 1.57 & 1.65 & 9.95 & 0.05 & 0.939 \\
14 & Green & 4.09 & 0.01 & 0.24 & 3.08 & 0.00 & 2.52 & 1.48 & 1.59 & 9.94 & 0.06 & 0.942 \\
15 & Green & 4.25 & 0.00 & 0.23 & 2.98 & 0.04 & 2.49 & 1.51 & 1.47 & 10.00 & 0.00 & 0.948 \\
16 & Green & 3.87 & 0.00 & 0.22 & 3.11 & 0.04 & 2.59 & 1.41 & 1.71 & 9.83 & 0.17 & 0.947 \\
$17 *$ & Red & 3.90 & 0.00 & 0.24 & 3.11 & 0.04 & 2.56 & 1.44 & 1.67 & 9.86 & 0.15 & 0.943 \\
\hline \multicolumn{2}{|l}{ Ti not included. Vac.: vacancy; ${ }^{\mathrm{IV}} \mathrm{Al}:$ on the basis of ${ }^{\mathrm{IV}} \mathrm{Al}+{ }^{\mathrm{IV}} \mathrm{Si}=4 ; \mathrm{Fe}$ rat. $=\mathrm{Fe} /(\mathrm{Fe}+\mathrm{Mg}) ;$} \\
$\Sigma$ Me: cation & sum; $17 *:$ berthierine. & & & & & & & & \\
\hline
\end{tabular}


Table 3.

\begin{tabular}{|c|c|c|c|c|c|}
\hline$\lambda(\mathrm{nm})$ & $v\left(\mathrm{~cm}^{-1}\right)$ & I & $\mathrm{W}$ & A & B \\
\hline $460 ?$ & 21740 & vw & $?$ & & \\
\hline $465 ?$ & 21705 & vw & $\mathrm{f}$ & & $\mathrm{X}$ \\
\hline$\sim 550$ & 18180 & $\mathrm{~m}$ & $\mathrm{~L}$ & & $X$ \\
\hline 605 & 16530 & VW & $\mathrm{f}$ & $X$ & \\
\hline$\sim 620$ & 16130 & vw & $\mathrm{f}$ & & $X$ \\
\hline 645 & 15505 & VW & $\mathrm{f}$ & $X$ & \\
\hline$\sim 710$ & 14085 & vw & $\mathrm{m}$ & & $X$ \\
\hline 895 & 11175 & VS & $\mathrm{L}$ & & $X$ \\
\hline 915 & 10930 & VS & $\mathrm{L}$ & $X$ & \\
\hline$\sim 1100$ & 9090 & $S$ & $\mathrm{~L}$ & $X$ & \\
\hline$\sim 1110$ & 9010 & $S$ & $\mathrm{~L}$ & & $X$ \\
\hline \multirow[t]{2}{*}{1415} & 7070 & $\mathrm{~W}$ & $\mathrm{f}$ & $X$ & \\
\hline & & vw & $\mathrm{f}$ & & $X$ \\
\hline$\sim 1580$ & 6330 & vw & $\mathrm{m}$ & $X$ & \\
\hline 1720 & 5815 & $\mathrm{w}$ & $\mathrm{m}$ & $X$ & $\mathrm{X}$ \\
\hline$\sim 1770$ & 5650 & vw & $\mathrm{f}$ & $X$ & $X$ \\
\hline 2020 & 4950 & W & $\mathrm{m}$ & $X$ & \\
\hline 2180 & 4585 & w & $\mathrm{f}$ & $X$ & $X$ \\
\hline 2270 & 4405 & $\mathrm{~m}$ & $\mathrm{f}$ & $X$ & $X$ \\
\hline 2320 & 4310 & $\mathrm{~W}$ & $\mathrm{f}$ & $X$ & $X$ \\
\hline 2370 & 4220 & $\mathrm{~m}$ & $\mathrm{~m}$ & $X$ & $\mathrm{X}$ \\
\hline \multicolumn{6}{|c|}{$\begin{array}{l}\text { Intensity scale (I): VS very strong; S strong; } \\
\text { m medium; w weak; vw very weak. } \\
\text { ?: doubtful. Width scale (W): L large; } \\
\text { m medium; f fine. }\end{array}$} \\
\hline
\end{tabular}


Table 4.

\begin{tabular}{|c|c|c|c|c|c|c|c|}
\hline Species & Structural formula & Polytype & $\beta\left(^{\circ}\right)$ & $\mathrm{V}\left(\AA^{3}\right)$ & $\begin{array}{l}\mathrm{Fe} \\
\text { ratio }\end{array}$ & ${ }^{\mathrm{IV}} \mathrm{Al}$ & Ref. \\
\hline Chamosite & $\begin{array}{l}\left(\mathrm{Fe}_{3.42} \mathrm{Mg}_{1.29} \mathrm{Al}_{1.29}\right) \\
\quad\left(\mathrm{Si}_{2.68} \mathrm{Al}_{1.32}\right) \mathrm{O}_{10}(\mathrm{OH})_{8}\end{array}$ & $\mathrm{Ib}$ & 90.01 & 712.85 & 0.726 & 1.32 & $S \& B$ \\
\hline Chamosite & $\begin{array}{l}\left(\mathrm{Fe}_{2.72} \mathrm{Mg}_{1.77} \mathrm{Al}_{1.33} \mathrm{Mn}_{0.08} \square_{0.1}\right) \\
\quad\left(\mathrm{Si}_{2.85} \mathrm{Al}_{1.145} \mathrm{Ti}_{0.005}\right) \mathrm{O}_{10}(\mathrm{OH})_{8}\end{array}$ & $\mathrm{IIb}$ & 97.23 & 706.74 & 0.606 & 1.145 & $\mathrm{~W} \& \mathrm{~B}$ \\
\hline Clinochlore & $\begin{array}{l}\left(\mathrm{Fe}_{1.69} \mathrm{Mg}_{2.96} \mathrm{Al}_{1.275}\right) \\
\quad\left(\mathrm{Si}_{2.624} \mathrm{Al}_{1.376}\right) \mathrm{O}_{10}(\mathrm{OH})_{8}\end{array}$ & $\mathrm{IIb}$ & 96.35 & 703.14 & 0.363 & 1.376 & $\mathrm{R} \& \mathrm{~B}$ \\
\hline Clinochlore & $\begin{array}{l}\left(\mathrm{Fe}_{1.88} \mathrm{Mg}_{5.53}\right) \\
\quad\left(\mathrm{Si}_{2.61} \mathrm{Al}_{1.39}\right) \mathrm{O}_{10}(\mathrm{O} \mathrm{H})_{8}\end{array}$ & $\mathrm{IIb}$ & 97.2 & 701.74 & 0.254 & 1.39 & Zan. \\
\hline Clinochlore & $\begin{array}{c}\left(\mathrm{Fe}_{0.269} \mathrm{Mg}_{4.715} \mathrm{Al}_{0.694} \mathrm{Fe}_{0.109} \mathrm{Cr}_{0.128} \mathrm{Ni}_{0.011}\right) \\
\left(\mathrm{Si}_{3.056} \mathrm{Al}_{0.944}\right) \mathrm{O}_{10}(\mathrm{OH})_{8}\end{array}$ & $\mathrm{IIb}$ & 96.82 & 701.19 & 0.054 & 1.944 & $\mathrm{Z} \& \mathrm{~B}$ \\
\hline Clinochlore & $\begin{array}{c}\left(\mathrm{Fe}_{0.118} \mathrm{Mg}_{4.882} \mathrm{Al}_{0.841} \mathrm{Fe}_{0.102} \mathrm{Cr}_{0.004} \mathrm{Ti}_{.004} \square_{0.049}\right) \\
\quad\left(\mathrm{Si}_{2.96} \mathrm{Al}_{1.04}\right) \mathrm{O}_{10}(\mathrm{OH})_{8}\end{array}$ & $\mathrm{IIb}$ & 97.47 & 698.35 & 0.024 & 1.04 & Smy. \\
\hline $\begin{array}{l}\& \mathrm{~B}: \\
\mathrm{Zar}\end{array}$ & $\begin{array}{l}\text { hirozu \& Bailey (1965); W\&B: Walker \& Bi } \\
\text { : Zanazzi et al. (2006); Z\&B: Zheng \& Baile } \\
\qquad \mathrm{Fe} \text { ratio }=\mathrm{Fe}^{2+} /\left(\mathrm{Fe}^{2+}\right.\end{array}$ & $\begin{array}{l}(1992 \\
(1989 \\
\mathrm{Mg}) .\end{array}$ & $\mathrm{R} \& \mathrm{~B}:$ & $\begin{array}{l}\text { Rule } \\
\text { Smyth }\end{array}$ & Bailey & $\begin{array}{l}(198 \\
997) .\end{array}$ & \\
\hline
\end{tabular}


Table 5.

\begin{tabular}{|c|c|c|c|c|}
\hline Formula $\left(\left[\mathrm{O}_{10}(\mathrm{OH})_{8}\right]\right.$ omitted $)$ & \multicolumn{2}{|c|}{${ }^{\mathrm{IV}} \mathrm{Al} \mathrm{Fe} /(\mathrm{Fe}+\mathrm{Mg})$} & Reference & Deposit \\
\hline$\left(\mathrm{Fe}_{3.87} \mathrm{Mg}_{0.23} \mathrm{Mn}_{0.01} \square_{0.07} \mathrm{Al}_{1.74} \mathrm{~V}_{0.07}\right)\left(\mathrm{Si}_{2.33} \mathrm{Al}_{1.67}\right)^{*}$ & 1.67 & 0.944 & This study & $\begin{array}{l}\text { St. Aubin } \\
\text { (SA) }\end{array}$ \\
\hline$\left(\mathrm{Fe}^{2+}{ }_{4.14} \mathrm{Fe}^{3+}{ }_{0.07} \mathrm{Mg}_{0.40} \mathrm{Al}_{1.39}\right)\left(\mathrm{Si}_{2.50} \mathrm{Al}_{1.50}\right) * *$ & 1.50 & 0.912 & Orcel (1923) & $\begin{array}{c}\text { Bas Vallon } \\
(\mathrm{Bv})\end{array}$ \\
\hline$\left(\mathrm{Fe}_{4.12} \mathrm{Mg}_{0.07} \mathrm{Mn}_{0.01} \square_{0.11} \mathrm{Al}_{1.69}\right)\left(\mathrm{Si}_{2.56} \mathrm{Al}_{1.44}\right)$ & 1.44 & 0.983 & $\begin{array}{l}\text { Inoué \& Kogure } \\
\text { (2016) }\end{array}$ & Ashio (As) \\
\hline$\left(\mathrm{Fe}^{2+}{ }_{4.21} \mathrm{Fe}^{3+}{ }_{0.05} \mathrm{Mg}_{0.27} \mathrm{Mn}_{0.01} \mathrm{Al}_{1.46}\right)\left(\mathrm{Si}_{2.49} \mathrm{Al}_{1.51}\right)$ & 1.51 & 0.940 & Jiang et al. & Kidd Creek \\
\hline$\left(\mathrm{Fe}^{2+}{ }_{4.11} \mathrm{Fe}^{3+}{ }_{0.05} \mathrm{Mg}_{0.07} \mathrm{Mn}_{0.01} \mathrm{Al}_{1.48}\right)\left(\mathrm{Si}_{2.48} \mathrm{Al}_{1.52}\right)$ & 1.52 & 0.983 & $(1992$ & \begin{tabular}{c|}
$(\mathrm{KC}-$ \\
average $)$
\end{tabular} \\
\hline$\left(\mathrm{Fe}^{2+}{ }_{4.25} \mathrm{Mg}_{0.07} \mathrm{Mn}_{0.06} \mathrm{Al}_{1.50}\right)\left(\mathrm{Si}_{2.50} \mathrm{Al}_{1.50}\right)$ & 1.50 & 0.986 & & \\
\hline$\left(\mathrm{Fe}_{3.75} \mathrm{Mg}_{0.73} \mathrm{Mn}_{0.04} \square_{0.06} \mathrm{Al}_{1.42}\right)\left(\mathrm{Si}_{2.79} \mathrm{Al}_{1.21}\right)$ & 1.21 & 0.837 & $\begin{array}{l}\text { Fernandez et al. } \\
(1998)(\text { mean } 7 \\
\text { anal.) }\end{array}$ & $\begin{array}{l}\text { Zamora } \\
(\mathrm{Za})\end{array}$ \\
\hline$\left(\mathrm{Fe}_{3.44} \mathrm{Mg}_{0.20} \square_{0.6} \mathrm{Al}_{1.42}\right)\left(\mathrm{Si}_{2.70} \mathrm{Al}_{1.30}\right)$ & 1.33 & 0.945 & Chauvel (1971) & Brittany $(\mathrm{B})$ \\
\hline$\left(\mathrm{Fe}_{3.80} \mathrm{Mg}_{0.80} \mathrm{Al}_{1.40}\right)\left(\mathrm{Si}_{2.60} \mathrm{Al}_{1.40}\right)^{* * *}$ & 1.40 & 0.826 & $\begin{array}{l}\text { Chauvel (1990) } \\
\text { in Fernandez et } \\
\text { al. (1998) }\end{array}$ & World (Wr) \\
\hline
\end{tabular}


FIGURE CAPTIONS

(a)

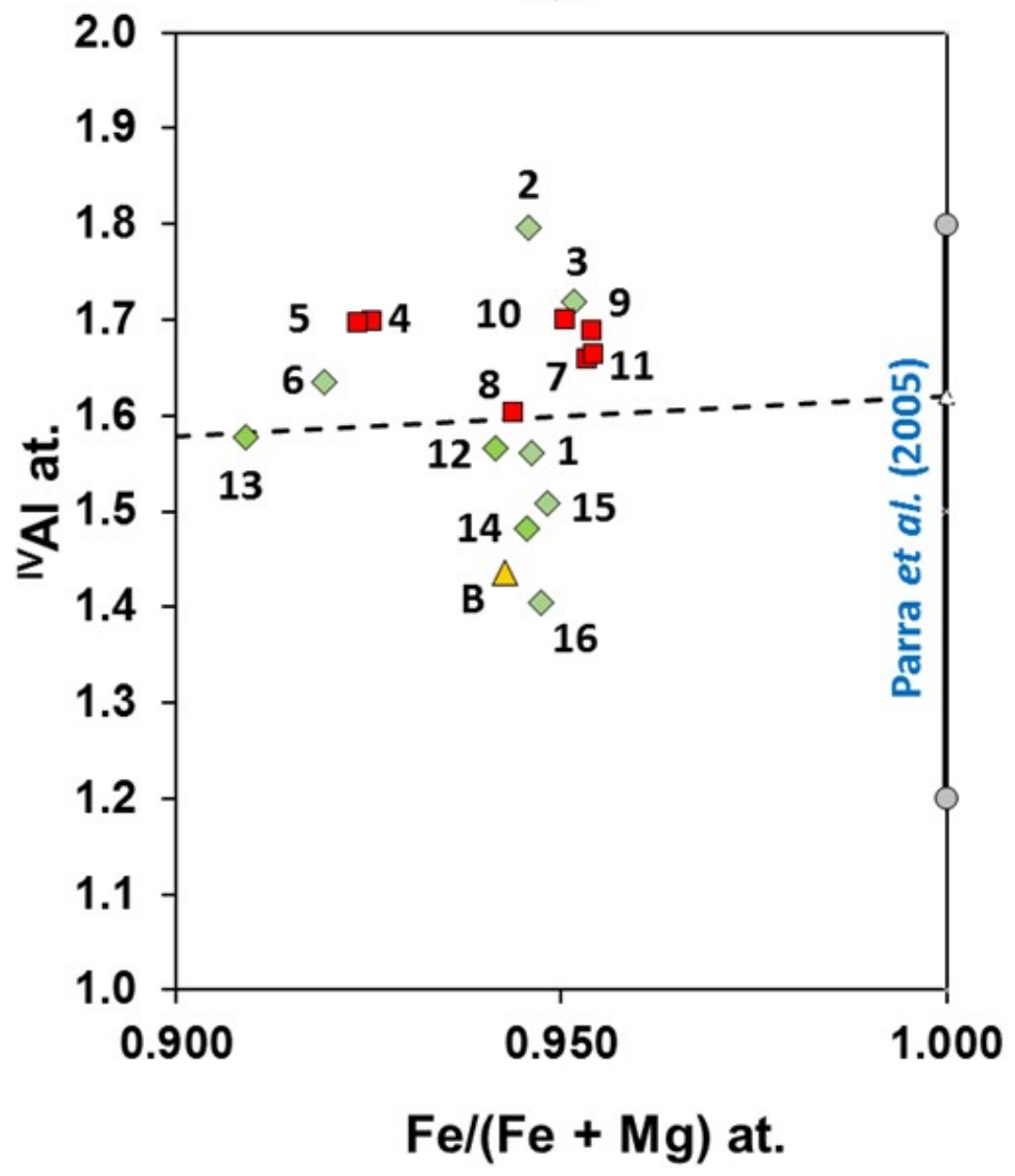


(b)

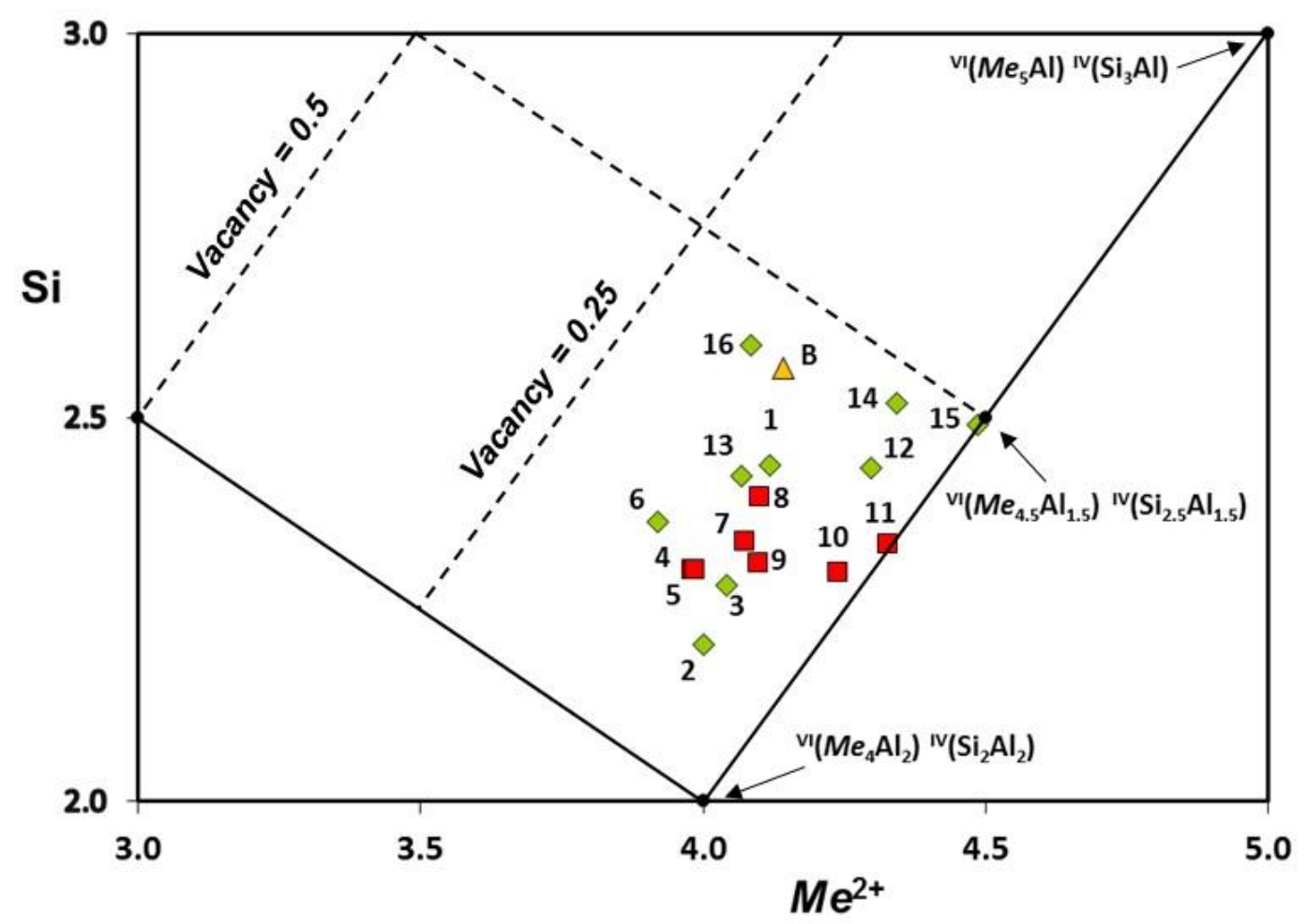

Fig. 1. Analyses of chamosite varieties from Saint-Aubin, according to Table 2b: a) in the ${ }^{\mathrm{IV}} \mathrm{Al}$ versus $\mathrm{Fe} /(\mathrm{Fe}+\mathrm{Mg})$ atom diagram. b) in the $\mathrm{Si}$ versus $\mathrm{Me}^{2+}$ at. diagram (Wiewióra \& Weiss, 1990). Dotted line of (a): regression curve for metamorphic chlorites (Zane et al., 1998). Red squares: orange-red chamosite; green diamonds: oolitic and hydrothermal green chamosite; yellow triangle: associated berthierine (B - No 17). "Si" and " $M e^{2+" \text { " }}$ cation number per $\mathrm{O}_{10}(\mathrm{OH})_{8} \cdot " \mathrm{Me}^{2+, "}=\mathrm{Mg}^{2+}+\mathrm{Fe}^{2+}$. 

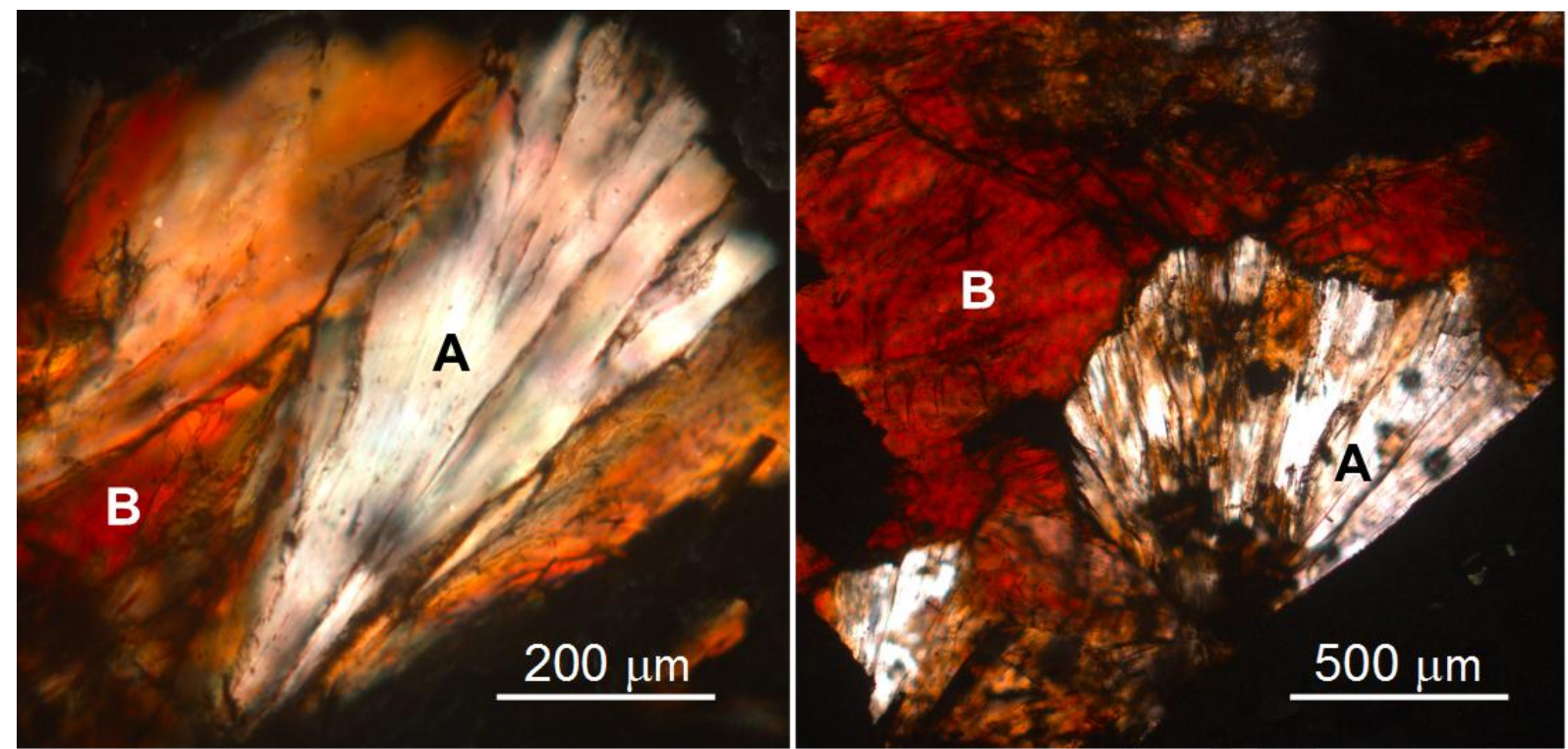

Fig. 2. Two examples of pleochroism of red chamosite (thin section, uncrossed polars). White

elongated areas (A type): polar sub-perpendicular to (001); dark orangey red areas (B type): polar sub-parallel to (001). Dark zones: pyrite.

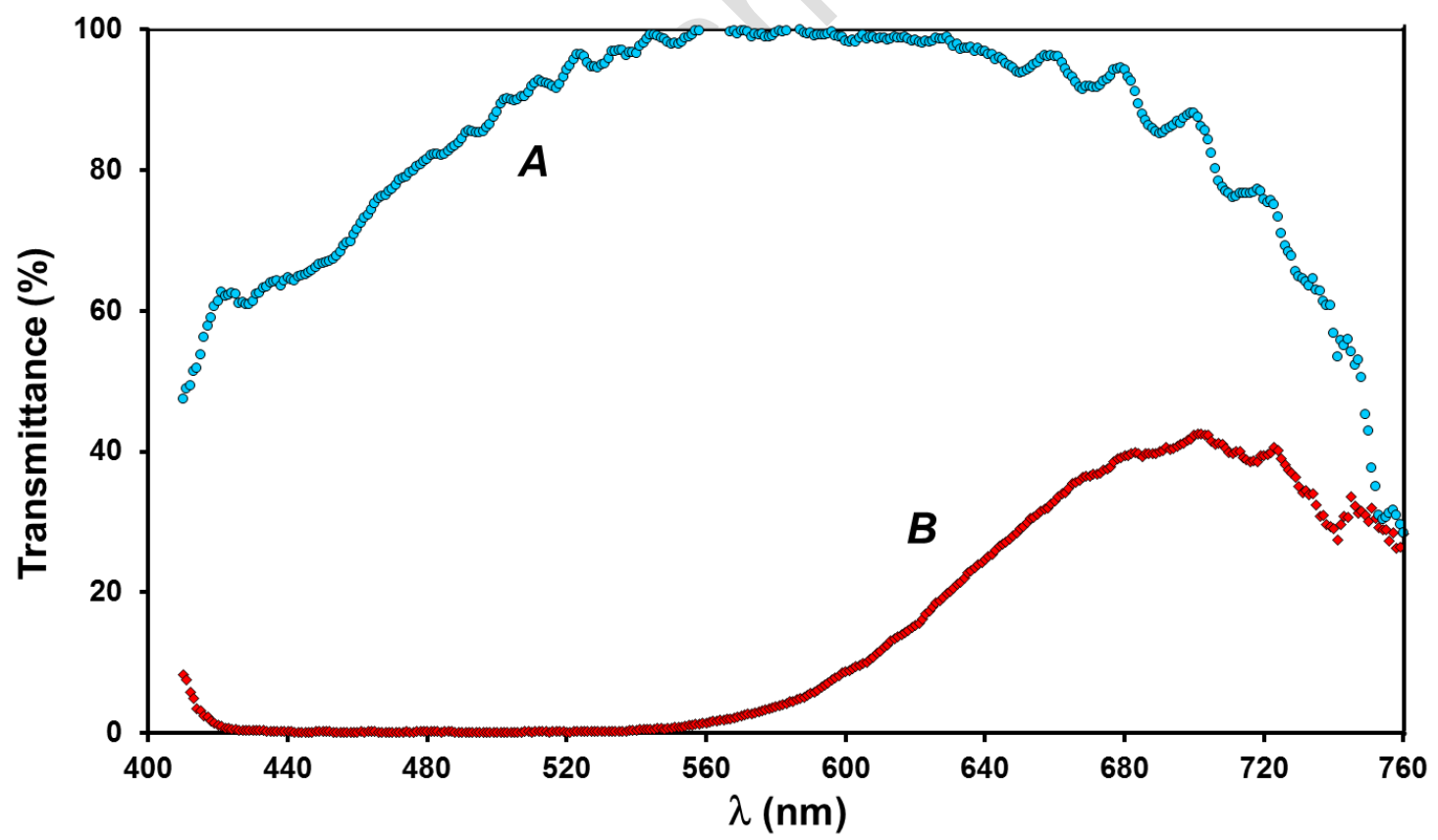

Fig. 3. Visible transmittance spectrum of red chamosite with polarizing microscope (thin section). A spectrum (blue-spot curve): $\mathbf{E} \perp(001)$ white; B spectrum (red-spot curve): $\mathbf{E} \mid(001)$ dominantly red. 


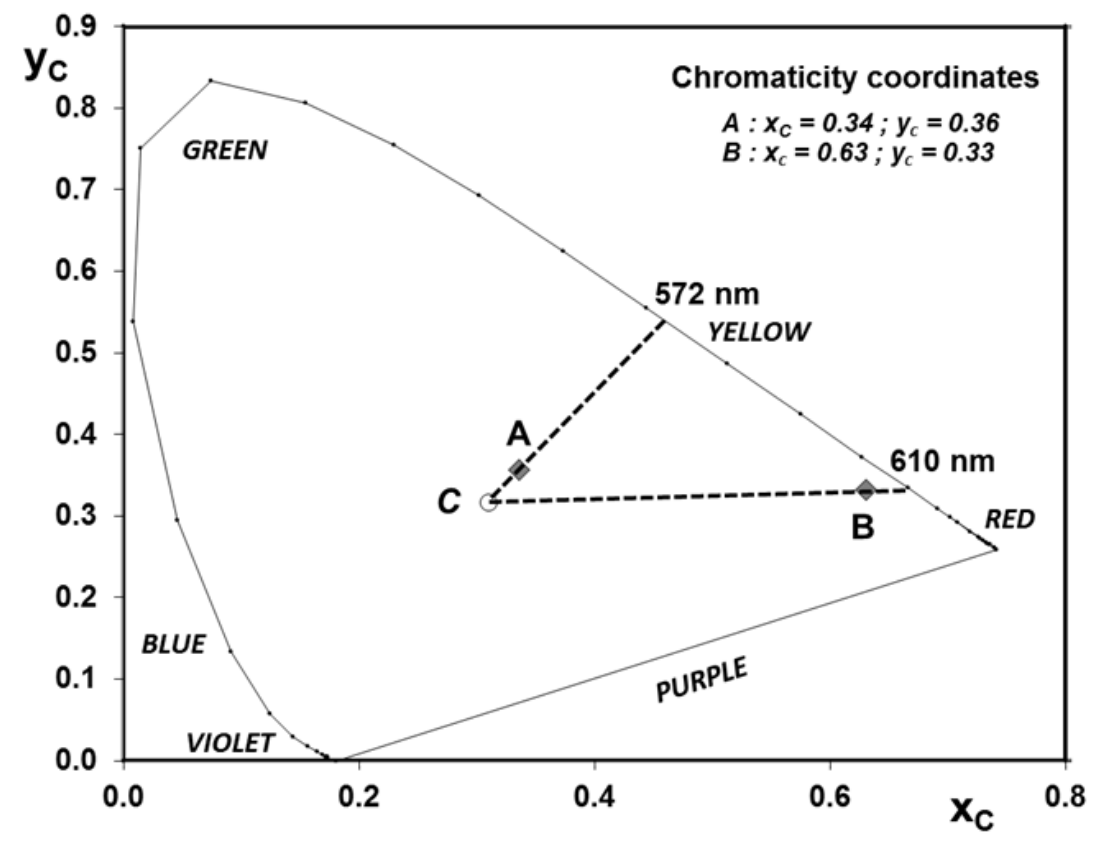

Fig. 4. Representation of pleochroism colours of red chamosite in the CIE chromaticity diagram. C: white colour (“average daylight” illuminant). Horseshoe-shaped line: spectrum locus (pure colours of the visible spectrum). Segment from violet to red: line of purple colours. A: $\mathrm{E} \perp(001) ; \mathrm{B}: \mathrm{E} \|(001)$. 


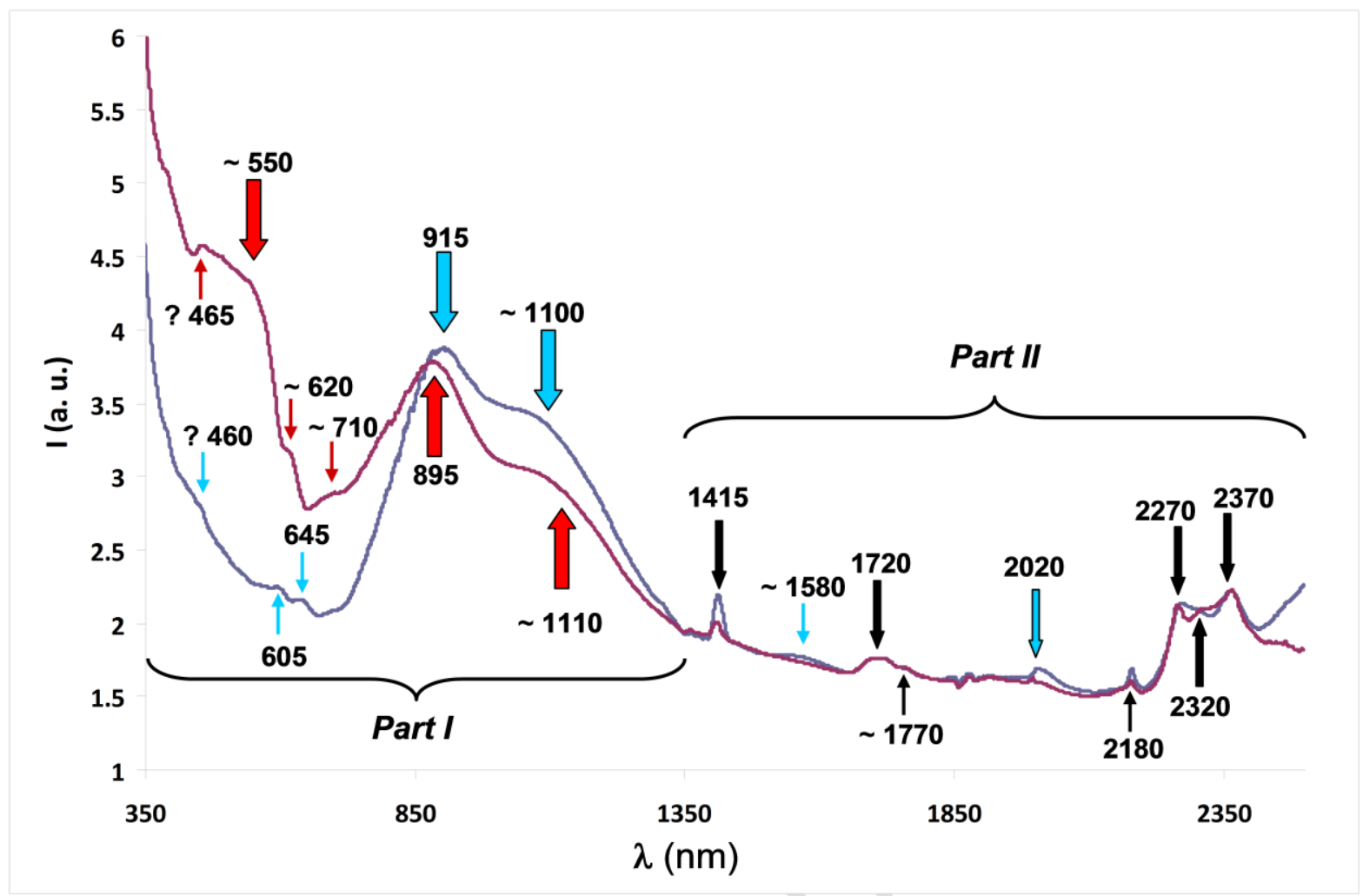

Fig. 5. Visible-NIR absorption spectrum of red chamosite (thin section; transmitted light).

Blue line: $\mathbf{E} \perp(001)$; red line: $\mathbf{E} \|(001)$. Absorbance I (a. u.: absorbance unit) versus wavelength $\lambda(\mathrm{nm})$. Blue and red arrows refer to specific band characteristics of blue and red spectra, respectively; black arrows in part II indicate common absorption bands. 
(a)

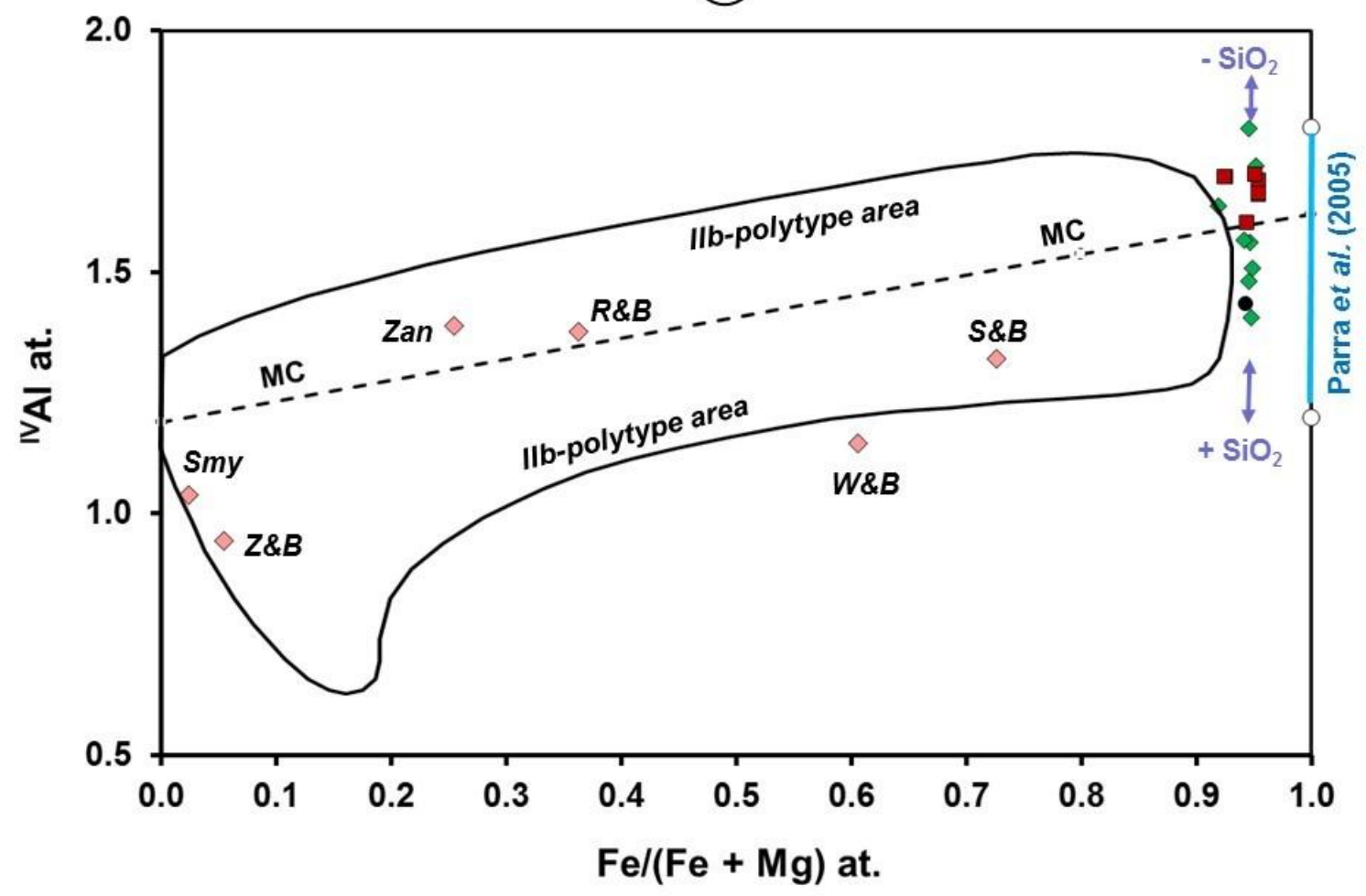

(b)

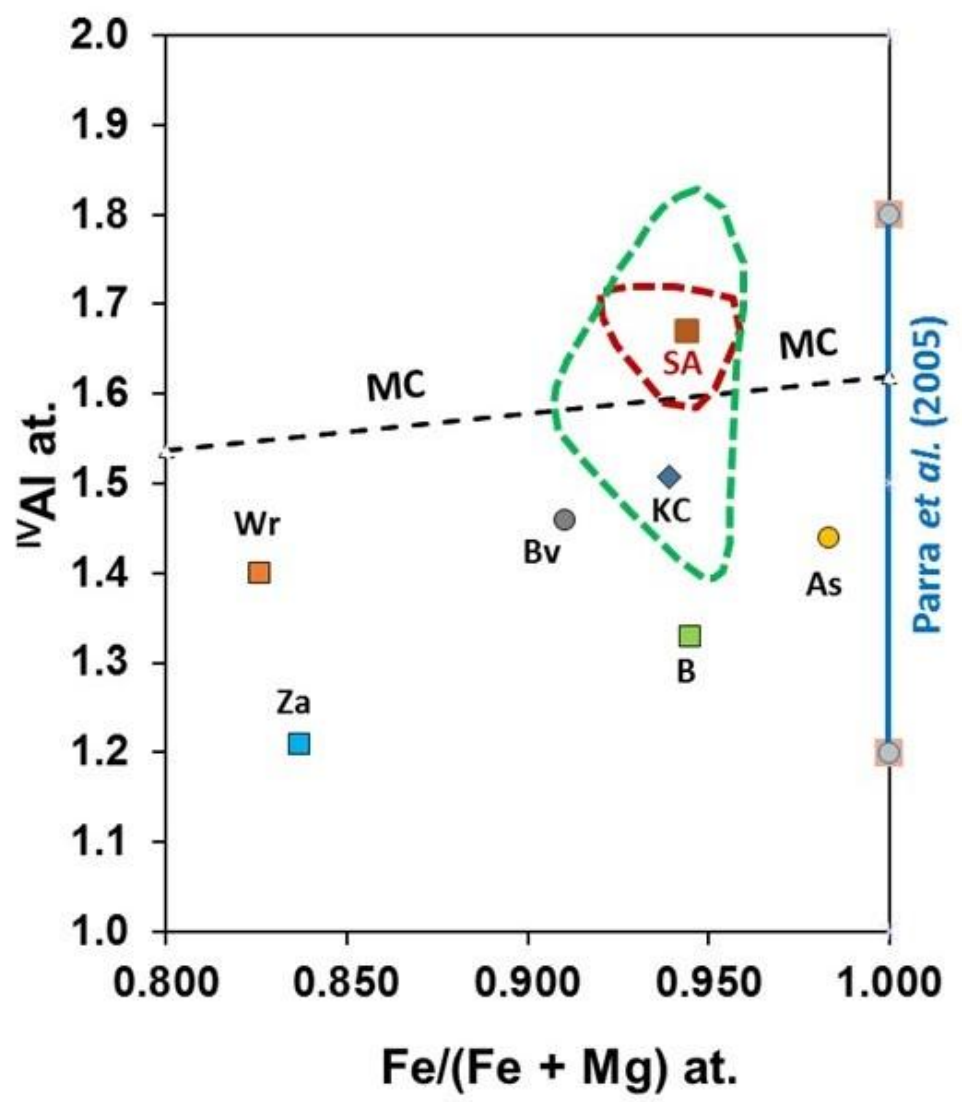


Fig. 6. Comparison of chamosite from Saint-Aubin with a sequence of chlorites from clinochlore to chamosite. a) Representation of chamosite analyses from Saint-Aubin in the clinochlore-chamosite series (green diamonds: green variety; red squares: red variety). Black circle: berthierine. Large composition field: area of II $b$ polytype of Brown \& Bailey (1962). Dotted line (MC): Regression line for metamorphic chlorite (Zane et al., 1998). Pink diamonds: Compositions from crystal structures (see Table 3). Blue segment: Tschermak substitution range in synthetic pure chamosite (Parra et al., 2005). b) Detail in the Fe-rich part of the series. Green and red tie-lines: composition fields of green and red chamosite varieties from Saint-Aubin, respectively. SA: mean composition of red chamosite. $\mathrm{Wr}, \mathrm{Za}, \mathrm{Bv}, \mathrm{B}$ : chamosite from oolitic ironstones; $\mathrm{KC}$ and $\mathrm{As}$ : chamosite from sulfide deposits (Symbols and references: see Table 5). 